Copy N! 19

APAE Memo - 305

Supplement 1

AF,C. Research and

Development Report

UC-81, Reactors - Power

[Special Distribution]

\title{
measurements and changes on \\ SM-1 core II during period \\ october 1, 1961 to May 30,1962
}

Contract No. AT[30-1]-2639

with U. S. Atomic Energy Commission

New Yurk Operations Office

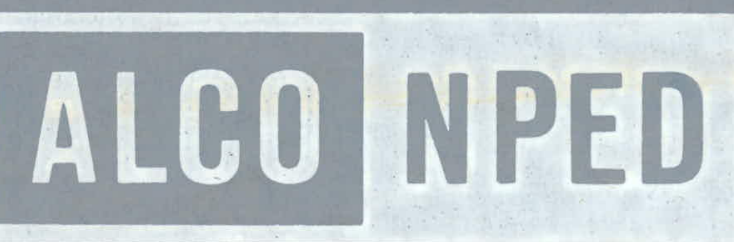

ALCO PRODUCTS, INC. NUCLEAR POWER ENGINEERING DEPARTMENT 


\section{DISCLAIMER}

This report was prepared as an account of work sponsored by an agency of the United States Government. Neither the United States Government nor any agency Thereof, nor any of their employees, makes any warranty, express or implied, or assumes any legal liability or responsibility for the accuracy, completeness, or usefulness of any information, apparatus, product, or process disclosed, or represents that its use would not infringe privately owned rights. Reference herein to any specific commercial product, process, or service by trade name, trademark, manufacturer, or otherwise does not necessarily constitute or imply its endorsement, recommendation, or favoring by the United States Government or any agency thereof. The views and opinions of authors expressed herein do not necessarily state or reflect those of the United States Government or any agency thereof. 


\section{DISCLAIMER}

Portions of this document may be illegible in electronic image products. Images are produced from the best available original document. 
APAE Memo-305

Supplement 1

AEC Research and

Development Report

UC-81, Reactors, Power

(Special Distribution)

\section{MFASUREMENTS AND CHANGES ON \\ SM-1 CORE II DURING PERIOD \\ OCTOBER 1, 1961 TO MAY 30, 1962}

By:

F.G. Moote

W.C. Best

J. D. Kortheuer

Approved By:

E.W. Schrader, Acting Project Engineer

Issued: : July 3 , : 1962

Contract No. AT (30-l) -2639

with U S. Atomic Energy Commission

New York Operations Office

ALCO PRÓDUCTS, INC.

Nuclear Power Engineering Department

Post Office Box 414

Schenectady 1., N.Y. 
AEC LEGAL NOTICE

This report was prepared as an account of Government sponsored work. Neither the United States, nor the Commission, nor any person acting on behalf of the Commission:

A. Makes any warranty or representation, expressed or implied, with respect to the accuracy, completeness, or usefulness of the information contained in this report, or that the use of any information, apparatus, method, or process disclosed in this report may not infringe privately owned rights:

B. Assumes any liabilities with respect to the use of, or for damages resulting from the use of any information, apparatus, method, or process disclosed in this report.

As used in the above, "person acting on behalf of the Commission" includes any employee or contractor of the Commission, or employee of such contractor, to the extent that such employee or contractor of the Commission, or employee of such contractor prepares, disseminates, or provides access to, any information pursuant to his employment or contract with the Commission, or his employment with such contractor.

\section{ALCO LEGAL NOTICE}

This report was prepared by Alco Products, Incorporated in the course of work under, or in connection with, Contract No. AT (30-1)-2639, issued by U.S.Atomic Energy Commission, NYOO; and subject only to the rights of the United States, under the provisions of this contract, Alco Products, Incorporated makes no warranty or representation, express or implied, and shall have no liability with respect to this report or any of its contents or with respect to the use thereof or with respect to whether any such use will infringe the rights of others. 


\section{DISTRIBUTION}

External

Copies...

$1-2$ New York Operations Office

U.S. Atomic Energy Commission

376 Hudson Street

New York 14, New York

Ättention: I.M. Adler

3

New York Operations Office

U.S. Atomic Energy Commission

376 Hudson Street

New York 14, New York

Attention: Library

$4-6$

U.S. Atomic Energy Commission

Washington 25, D.C.

Attention: Chief, Water Systems Project

Branch (Army Reactors)

Division of Reactor Development

Mail Station F-311

U.S. Atomic Energy Commission

Washington 25, D.C.

Attention: Chief, Evaluation and

Planning Branch

Civilian Reactors

Div . of Reactor Development

Mail Station F-311

8

U.S. Atomic Energy Commission

Chief, New York Patent Group

Brookhaven National Laboratory

Upton, New York

Attention: Harman Pöter 
External

Copies

9

Idaho Nuclear Power Field Office U.S. Army Eng. Reactors Group P.O. Box 2108

Idaho Falls, Idaho

10

U.S. Atomic Energy Commission

Reports and Statistics Branch

Division of Reactor Development

Washington 25, D.C.

$11-12$ Office of the Chief of Engineers

Dept. of the Army

Building $\mathrm{T}-7$

Washington 25, D.C.

Attention: Chief, Projects Branch Nuclear Power Division

13 - $15 \quad$ Nuclear Power Field Office

U.S. Army Engineer Reactors Group

Fort Belvoir, Virginia

Attention: Chief, Nuclear Power Field Office

Nuclear Power Field Office

U.S. Army Engineer Reactors Group:

Fort Belvoir, Virginia

Attention: O.I.C. SM-1

17 Chief, U.S. Army Reactors Group

Fort Greely, Alaska

APO 733

Seattle, Washington

Attention: O.I.C. SM-1A 
External

Copies.

18

Commanding Officer

U.S. Army Polar Research

and Development Center

Fort Belvoir, Vịnginia

Altentiun: Nuclear Power Ufficer

$19-21 \quad$ Office of Technical Information Extension

P: 0 . Box 62

Oak Ridge, Tennessee

22 Union Carbide Nuclear Corporation

Oak Ridge National Laboratory

Y-12. Building $9704-1$

P.O. Box "Y"

Oak Ridge, Tennessee

Attention: L.D. Schaffer

23 The Martin Company

P.O. Box 5042

Middle River , Maryland

Attention: AEC Contract Document Custodian

$24-25 \quad$ Combustion Engineering, Incorporated

Nuclear Division

Prospect Hill Road

Windsor, Connecticut

Attention: Mr. J.B. Anderson

26. Alco Products, Inc.

Post Office Box 145

Fort Belvoir , Virginia

Attention: W.C. Best 


\section{DISTRIBUTION (CONT'D)}

Internal

Copies

\begin{tabular}{|c|c|}
\hline 27 & K. Kasschau \\
\hline 28 & J.F. Haines \\
\hline 29 & J.G. Gallagher \\
\hline 30 & C.A. Bergmann \\
\hline 31 & C.R. Bergen \\
\hline 32 & J. Chupak \\
\hline 33 & P. Marsh \\
\hline 34 & R. Bell \\
\hline 35 & C. Klotz \\
\hline 36 & E.C. Edgar \\
\hline 37 & P.E. Bübé \\
\hline 38 & W.T. Williams \\
\hline 39 & F.G. Moote \\
\hline 40 & E.W. Schrader \\
\hline 41 & R.E. Neville \\
\hline $2-43$ & Critical Facility (2) \\
\hline $4-50$ & NPED File \\
\hline
\end{tabular}




\section{ABSTRACT}

Tests at the SM-1 reactor are reported for the period October 1,1961 to May 31, 1962. Loading changes were made. in SM-1 Core. II during the scheduled semi-annual shutdowns in October-November 1961' and April-May 1962. Core physics tests. include control rod bank calibrations, bank position at several temperature and xenon poison conditions vs core changes and energy release, shutdown neutron source decay and startup channel testing, and critical rod positions for stuck rod configurations. Shielding measurements of gamma radiation in the rod drive pit were made, and dose rates from spent fuel elements as a function of the depth of the water shield were obtained. A lift mechanism for the $\mathrm{BF}_{3}$ detector of one startup channel was.installed and preliminary testing completed. Water chemistry and radiochemistry tests included a changeover to high $\mathrm{pH}$ for the primary coolant, fịssion product monitoring for iodine measurement of dose rates on primary system during shutdown, radiochemical analysis of primary water and crud, and change of metal corrosion samples. Buildup of radioactivity in the demineralizer was monitored by radiation surveys and film badge exposures. 
THIS PAGE

WAS INTENTIONALLY

LEFT BLANK 


\section{TABLE OF CONTENTS}

\section{$\underline{\text { Page }}$}

ABSTRACT - - - - - - - - - - - - - - - - - - - - - - - - - - vii

1.0 SUMMARY - - - - - - - - - - - - - - - - - - $1-1$ i

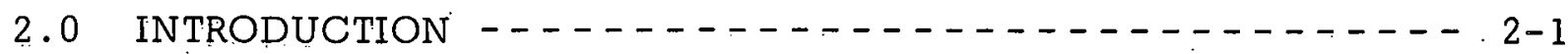

3.0 LOADING CHANGES IN SM-1 CORE II - - - - - - - - - - 3-1

3.1 Shutdown October 16 lo November 17, 1961

at 1.51 MWYR Burnup _..-

3.2 Shutdown April 5 to May 19, 1962 at 2.68 MWYR

Burnup -- - - -.-- - - - $-\cdots-\ldots$

4.0 CORE PERFORMANCE OF SM - I CORE II BY ROUTINE AND

SPECIAL MEASUREMENTS - - - - - - - - - - - - - - $\quad 4-1$

4.1 Test A322-Startup Channel Evaluation and Source

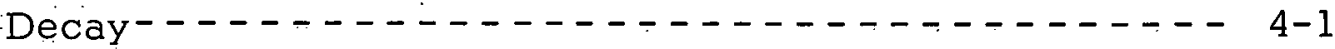

4.2 Test A323-Five Rod Bank Position as a Function of

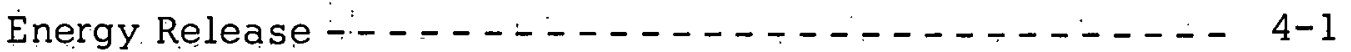

4.3 Test A325-Five Rod Bank Calibration - _. _. _ . . . - 4-6.

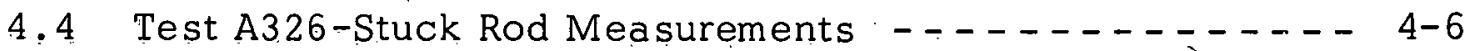

4.5 Tests A308 and A310-Control Rod Calibrations-_. - - - - 4-9

4.6 Test A31.1-Temperature Coefficient _... $\ldots \ldots \ldots \ldots$ 4- 12

5.0 SHIELDING MEASUREMENTS - -

5.1 Test A407-Rod Drive Pit Gamma Radiation - - . - - - - 5-1

5.2 Test A408-Gamma Dose Rate from Spent Fuel.Elements - - 5-5

6.0 NUCEEAR INSTRUMENTATION $-\cdots-\cdots-\cdots-\cdots-\cdots-\cdots-\cdots-\cdots$

6.1 Test A503-Lifting Mechanism for Startup Channel

$\mathrm{BF}_{3}$ Counter - - - - - - - - - - - - $-\ldots-1$ 
$\underline{\text { Page }}$

7.0 CHEMISTRY AND RADIOCHEMISTRY TESTS $-\ldots \ldots \ldots$

7.1 Test Al 09-Evaluation of Industrial Instrument Model

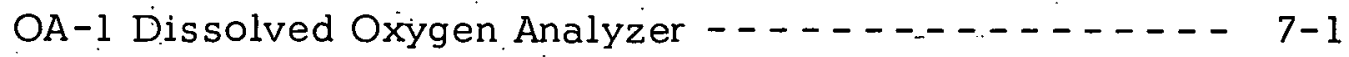

7.2 Test Al 12-High pH Coolant Test _-

7.3 Test A200-Fission Product Monitoring -

7.4 Test A202-Measurement of Dose Rates on Primary System During Reactor Shutdowns. - - - -

7.5 Test A203-Sampling of Primary System Water and Crud for Radiochemical and Chemical Analysis - - - - - - 7-2

7.6. Test A204-Sampling of Metal Coupons for Radiochemical

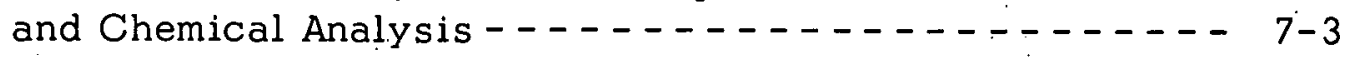

7.7 Test A213-Short-Lived Activity and Decay Rates.of Primary System Water and Crud -............ 7-3

7.8. Tests A214,A215 and A216-Dose Rates on the Demineralizer during Operation and after Shutdown - . - . - 7- 4

7.9 Test A220-Determination of $\mathrm{Mn}^{56}, \mathrm{Cs}^{138}$ and $\mathrm{Ba}^{139} \mathrm{Con-}$ centrations in SM-1 Primary Coolant - _......... 7-4

8.0 REFERENCES $-\ldots-\ldots-\ldots-\ldots-\ldots-\ldots-\ldots-\ldots$ 


\section{LIST OF FIGURES}

Figure

Title

$\underline{\text { Page }}$

3.1

SM-1 Core II Original Loading, June 1961

$3-2$

3.2 SM-1. Core II Loading Following October-November

$3-3$ 1961 Shutdøwn

3.3 SM-1 Core II Loading Following April-May 1962 Shutdown

$3-4$

4.1 Shutdown Neutron Source Decay (SM-1 Core II)October-November 1961 shutdown

4.2 Shutdown. Neutron Source Decay (SM-1 Core II) - . April-May 1962 Shutdown

4.3 Five Rod Bank Position Vs Core II Energy Release

4.4 Five Rod Bank Calibrations, October 1961 April 1962

Five Rod Bank Calibrations, May 1962

$4-8$

4.6

Control Rod·A Calibrations

$4-10$

$4: 7$

Control Rod C Calibrations

$4-11$

$4: 8$

Temperature Coefficient

$4-14$

5.1

Radiation Survey Point Location - Rod Drive Pit

$5-4$

5.2

Gamma Radiation Dose Rate from spent Fuel Elements

$5-7$

6.1

Startup Channel Count Rate Vs BF3 Chamber Height

$6-3$ 


\section{THIS PAGE}

WAS INTENTIONALLY

LEFT BLANK 


\section{LIST OF TABLES}

$\underline{\text { Table }}$

$\underline{\text { Title }}$

Page

4-1 Five Rod Bank. Position Vs Core II Energy Release

$4-4$

$4-2$

Stuck Rod Measurements

$4-9$

$4-3$

Temperature Coefficient

$4-13$

$5-1$

Gamma Radiation Survey of SM-1 Rod Drive Pit, October 1961

$5-1$

5-2 Gamma Radiation Survey of SM-1 Rod Drive Pit., Arpil 1962

$5-2$

5-3 Gamma Radiation Dose Rates from SM-1 Core I Spent Fuel Elements

$5-6$

6-1 Startup Channel Lift Mechanism, Count Rate Vs $\mathrm{BF}_{3}$ Chamber Height

$6-2$ 


\subsection{SUMMARY}

This report provides an outline of the test program conducted at the $\mathrm{SM}-1$ reactor site at Fort Belvoir in the eight-month period, October 1。1961 to May 30, 1962, and covers all testing following the startup and initial testing of $\mathrm{SM}-1$ Core II, reported in APAE Memo-305. (5)

It includes the first two semi-annual scheduled shutdowns of Core II, and the core loading changes which were made. In the October-November 1961 shutdown, two high burnup Core I elements $S y U$ and $S \& \perp$ were removed, as well as a Type 3 element SM-2B. The Martin test element PM-1-M-2 and two spare elements were loaded. In the April-May 1962 shutdown, the SM-2B element was replaced in the core, and a prototype silver-cadmium-indium absorber SCI-3 was installed, replacing europium absorber EUSS-4 in control rod 3.

Core physics tests were run as operating conditions permitted. During each of the two long shutdowns, the neutron source decayed with a half-life of approximately 12.8 days, in good agreement with the Bal40-Lal40 photoneutron precursor. The five rod bank position as a function of core energy release changed with a slope similar to that of Core I. The core changes in October-November 1961 caused a reactivity increase of about 2.1 dollars. The core changes in April-May 1962 caused no perceptible reactivity change. Five rod bank calibrations were continued at every opportunity. The calibration curve shows no significant change since Core II startup. Critical rod positions for stuck rod configurations were measured on two occasions. In all cases, complete withdrawal of two rods plus partial withdrawal of a third was necessary to bring the reactor critical. Calibrations of control rods $A$ and $C$ were run after the core changes in May 1962. Temperature coefficient measurements were made in the regions above $200^{\circ} \mathrm{F}$ and $400^{\circ} \mathrm{F}$, showing reasonable agreement with measurements at Core II startup.

Shielding measurements were continued during scheduled shutdowns. The gamma radiation in the rod drive pit was surveyed in October and April, confirming previous measurements. The April 1962 surveys included more detailed mapping using film badges. Dose rates from spent fuel elements under 3 to $4 \mathrm{ft}$ of water were measured as a function of water depth. The results agreed well with previous measurements.

The lifting mechanism for the startup channel $\mathrm{BF}_{3}$ counter was installed and preliminary tests made. The Pyle connector used for the vapor container penetration was satisfactory. The count rate vs position agreed well with neutron foil activation in the instrument well.

Coordination and supervision of work performed in conjunction with chemistry (100 series) and radiochemistry (200 series) tests was carried out. Data and samples for eleven tests were obtained for evaluation and/or shipment 
to Schenectady: for analyses. SM-1 startup and operation at high $\mathrm{pH}$, (Test Al12) proceeded on schedule with no major problems. Preliminary evaluation of dose rate data indicates that the rate of activity buildup on primary system surfaces has decreased. Results of the gross fission product iodine test (A200) indicated that no significant cladding defects. have occurred in Core. II from June 1961 to April 1962. 


\subsection{INTRODUCTION}

Under the requirements of the Program Plan for Engineering Support and Development for Army Pressurized.Water Power Plants, (I) a small research and development staff is maintained at Fort Belvoir. This group performs several functions, an important one being a liaison contact between the Army Operations Branch and the project engineer and task engineers. who plan and supervise the tasks which make up the program plan.

Another service, closely assoclated with the liaison function, is to offer assistance on special problems which may arise at the SM-1 plant, and communicate these problems to the appropriate task engineers and specialist groups. While the responsibility for satisfactory and safe operation rests with the Army Operations Branch, the R \&:D staff and all associated organizations certainly have an interest in helping to maintain this satisfactory and safe situation. It is therefore important to have good working and personal relationship with the Operations Branch, so that mutual confidence and easy communication are maintained.

The major role is to assist with the tests carried out at the $S M-1$ reactor. This includes assistance with preparation of test procedures and review of these by Army and AEC organizations. The tests themselves are run by Army operations staff as far as possible, with supervision and assistance from the $R \& D$ staff, and if necessary, from the task engineers and their specialists.

Another duty is to assist in the preparation of periodic test programs and schedules covering all the tests at the SM-1 reactor. Two such test programs were prepared and submitted in this six months period under. Task 11 of the program plan. The first covered October 1961 to March $1962,(2)$ and the second covered the next six months period, April to September 1962. (3)

The following report covers the information obtained from tests conducted at the SM-1 reactor in the eight month period, October 1,1961 to May 31, 1962 . Most of this information is also included. in the six months summary report for this program; under the various tasks and subtasks. (4) Previous test data.is summarized in the startup report for $S M-1$ Core II ${ }^{(5)}$ and the summary report of physics measurements. on SM-1 Core I. (6) 


\subsection{LOADING CHANGES IN SM -1 CORE II}

\subsection{SHUTDOWN OCTOBER 16 TO NOVEMBER 17,1961, AT 1.51 MWYR BURNUP}

At the time of this scheduled semi-annual shutdown, operation of $\mathrm{SM}-1$ Core II had totalled 1047.24\% ${ }^{\circ} \mathrm{F}$ days or 1.51.MWYR, representing a load factor of $41 \%$ for the four months since Core II startup.

The fïllüwiny cuite luadlny changes were carried out during this shutdown. Two high burnup elements, S80 and S81, were removed from lattice positions 35 and 54 respectively, and replaced by elements $14 \mathrm{~V}$ (transferred from position 26. and S83 (spare, from fuel vault). One type 3 core element, SM-2B, was removed from lattice position 52 and replaced by a spare element S63. The Martin test element PM-1-M-2 was loaded in position.26. Figure.3.1 shows the original loading of SM-1 Core II in.June 1961. Figure 3.2 shows the loading after the October changes were completed.

During this shutdown, several fuel elements and control rod absorbers were visually examined through the periscope: in the reactor tank. This examination has been reported in the latest six months summary report. (4)

Another change made at this time was the removal of the NRL flux monitors from their irradiation position on the core support ring. These monitors. were installed in. June 1961 at the time of Core II loading. They were shipped to the Naval Research Laboratory for evaluation.

Element SM-2B was shipped to Oak Ridge National Laboratory for hot cell examination, and returned for reinsertion in Core II.

\section{$3: 2$ SHUTDOWN APRIL 5 TO MAY 19, 1962, AT 2.68 MWYR.BURNUP}

The second scheduled semi-annual shutdown of SM-1 Core II occurred on April 5, 1962, when burnup totalled $1863.77^{\circ} \mathrm{F}$ days or $2.86 \mathrm{MWYR}$, representing a load factor of $31 \%$ since Core II startup.

The following core loading changes were carried out. Element S63 was removed from core position 52 , and the type 3 element SM-2B was returned to that position. Absorber EUSS 4 was removed from control rod 3 in core position 64. A new prototype silver-cadmium-indium absorber SCI-3 was inserted in rod 3 . Figure 3.3 shows the core configuration after these loading changes were completed. 


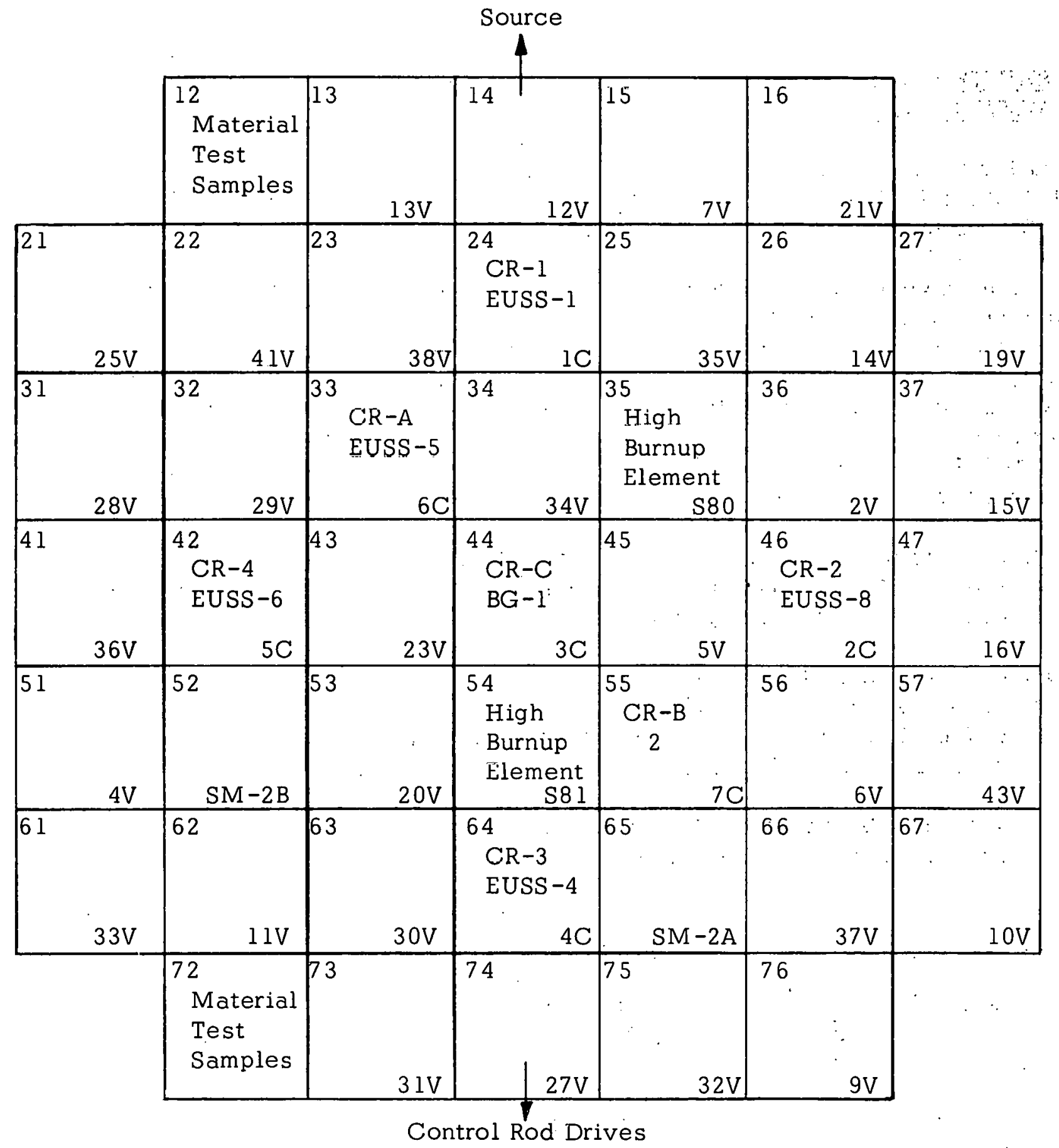

Figure 3.1. SM-1 Core II Original Loading, June 1961 


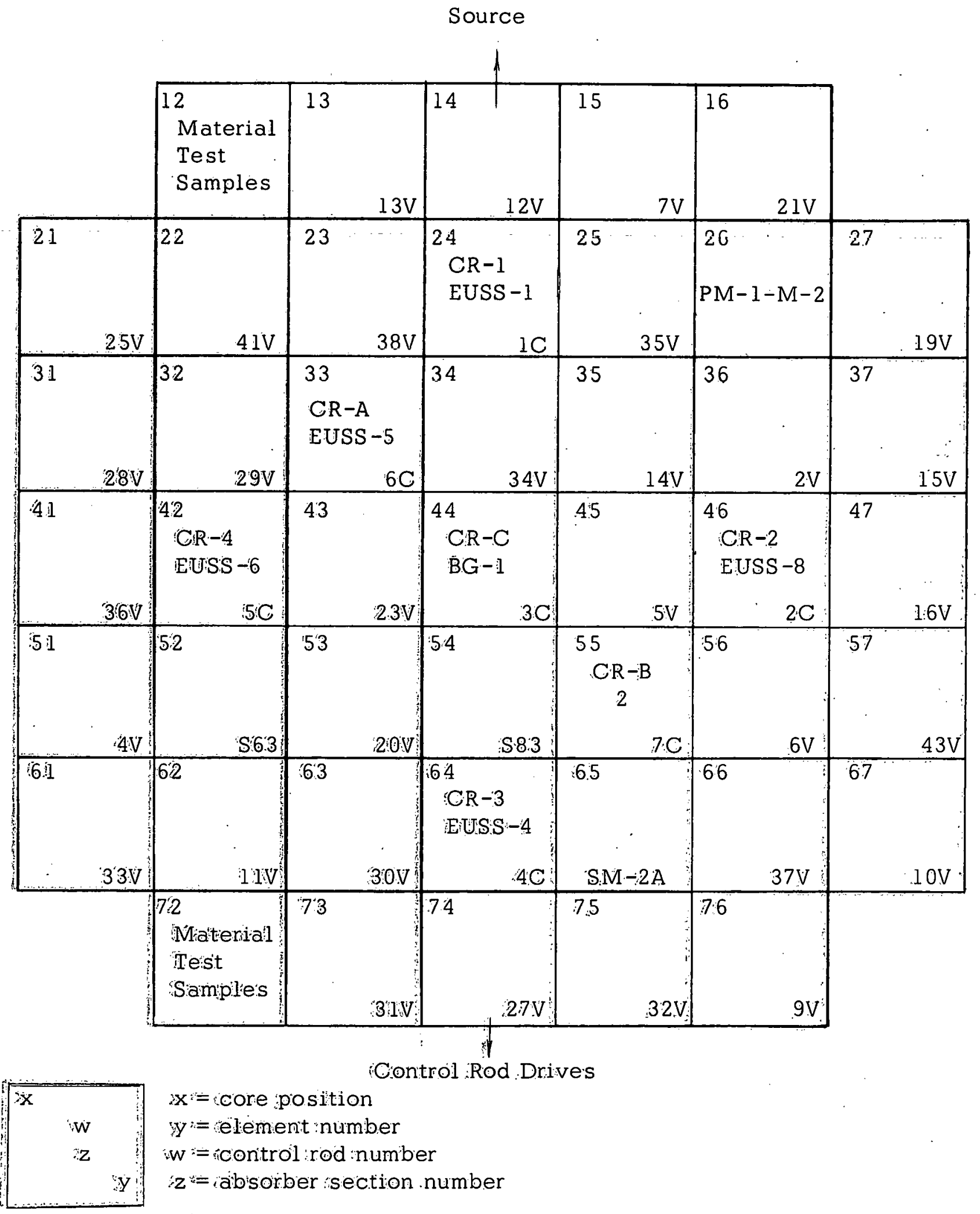

Figure 3..2. SM-1 Core II iLoading Following October - November, 19.61 Shutdown 


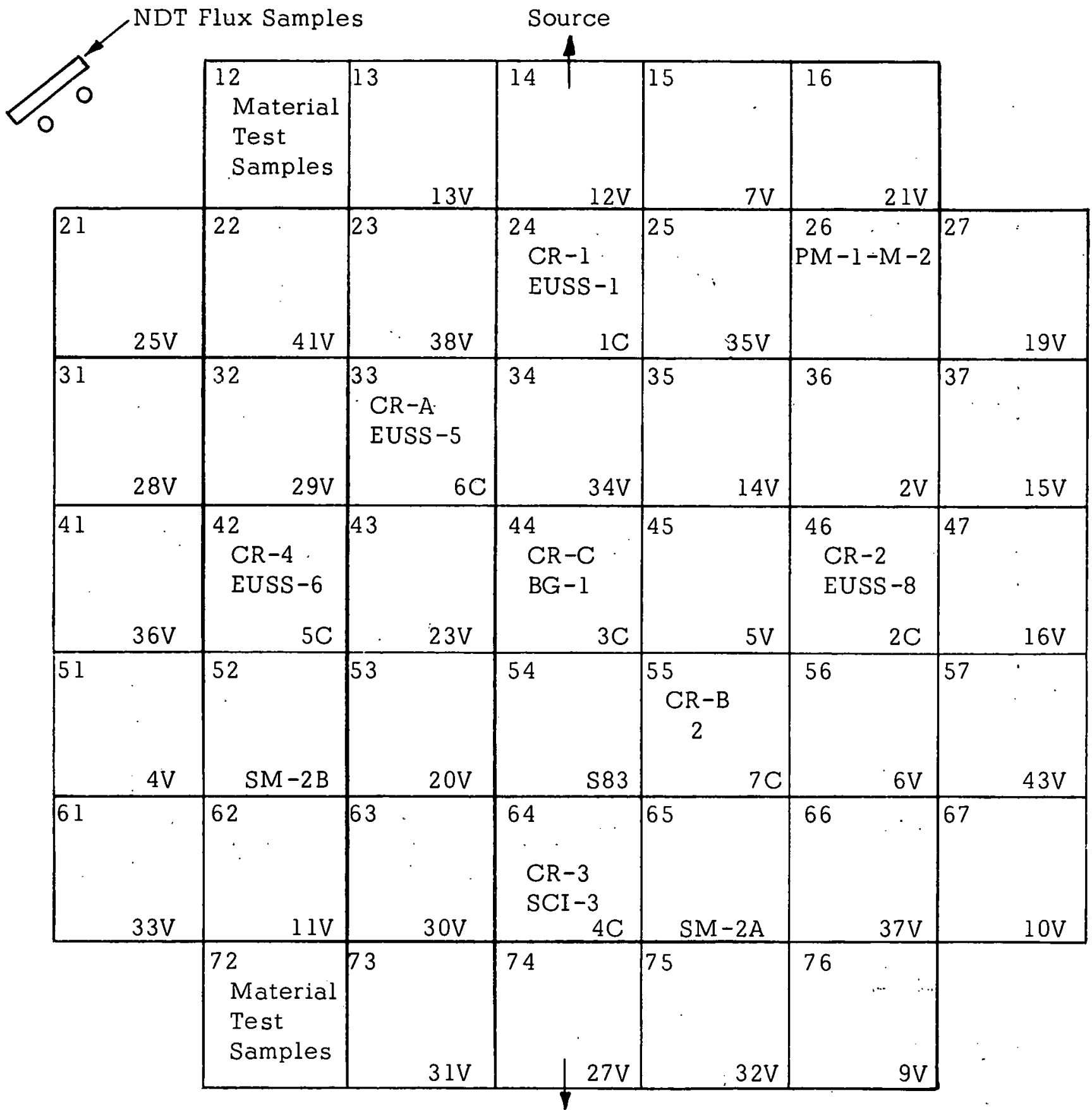

Control Rod Drives

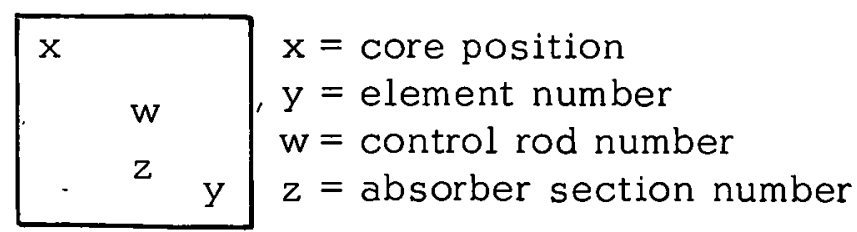

Figure 3.3. SM-1 Core II Loading Following April-May 1962 Shutdown 
During this shutdown an IZOD specimen of reactor vesisel steel was removed from the core support ring. A new NRL sample for fast flux monitoring and radiation damage studies was placed in the vacant sample tubes on the support ring.

Later, the high burnup element 581 was removed from the spent fuel pit and loaded into the ORNL shipping cask, along with the IZOD sample. Both were shipped to Oak. Ridge National Laboratory for hot cell examination and radiation damage studies. 


\subsection{CORE PERFORMANCE OF SM-1. CORE II BY ROUTINE AND SPECIAL MEASUREMENTS}

\section{1 TEST A322-STARTUP CHANNEL EVALUATION AND SOURCE DECAY}

The purpose of this test is to evaluate the neutron source used in the reactor. Startup channel count rate is measured as a function of time after shutdown. This data is interpreted to yield an evaluation of the adequacy and - time dependent behavior of the neutron source and photoneutron emitters.

An important part of Test A322 is the calibration of startup channels, since the operating parameters of the startup channels must be properly adjusted to compensate for gamma radiation, thermal and aging effects on the $\mathrm{BF}_{3}$ chambers, and to detect any electronic difficulties.

The test was run throughout the October-November 1961 and the AprilMay 1962 shutdowns. The source decay rate had a half-life close to 12.8 days for each period, corresponding to the Bal40-La: 140 photoneutron source. The count rate after five weeks was about 1 and $2 \mathrm{cps}$ in Channels 1 and. 2 . respectively. Data is plotted in Fig.4.1 and 4.2. Startup channel.voltage calibrations and pulse height calibrations for both channels were run several times during the eight month period. 'Some data was. taken at high voltage $(2200-12450)$ and low gain as well as the former operating voltage (1850 - 1950) and high gain as determined at Core II startup. These new settings show promise of improved performance, and should be further tested and evaluated.

The arbitrary requirement for $2 \mathrm{cps}$ in each startup channel cannot be met . with the existing neutron source after several weeks of shutdown. The practice of adjusting pulse height or gain settings to bring the count rate up to this level is not recommended, as it introduces noise pulses to make up the deficiency. It is recommended that this arbitrary requirement be withdrawn until a stronger source is obtained: The startup channels should be,calibrated and optimum settings determined during each long shutdown. The source decay should then

- be followed at these settings, to ensure that a correct neutron count rate is available before reactor startup.

\subsection{TEST A323-FIVE ROD BANK POSITION AS A FUNCTION OF ENERGY RELEASE}

The purpose of these measurements is to obtain data on the five rod bank position as a function of the total core energy released. During each reactor shutdown of $48 \mathrm{hr}$ or more duration, five rod bank positions were obtained for " the following conditions: low xenon for temperatures of ambient, $200^{\circ} \mathrm{F}, 300^{\circ} \mathrm{F}$, $400^{\circ} \mathrm{F}$ and $440^{\circ} \mathrm{F}$. When a full power run of 48 . hr or more was followed by a shutdown, bank positions at equilibrium xenon, $4400^{\circ} \mathrm{F}$, and peak xenon, $440^{\circ} \mathrm{F}$, 


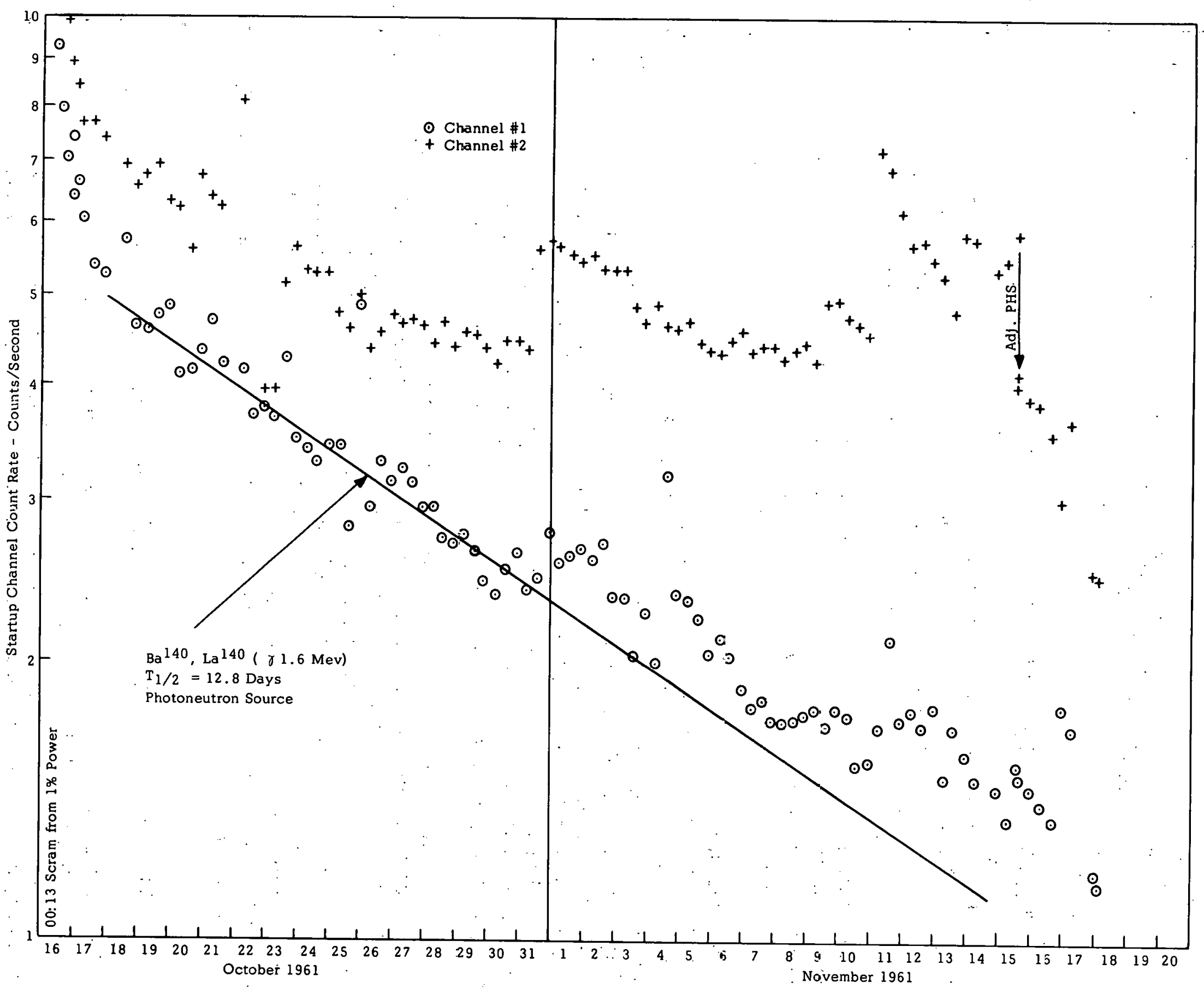

Figure 4.1

Shutdown Neutron Source Decay (SM-1 Core II)October-November 1961 shutdown 


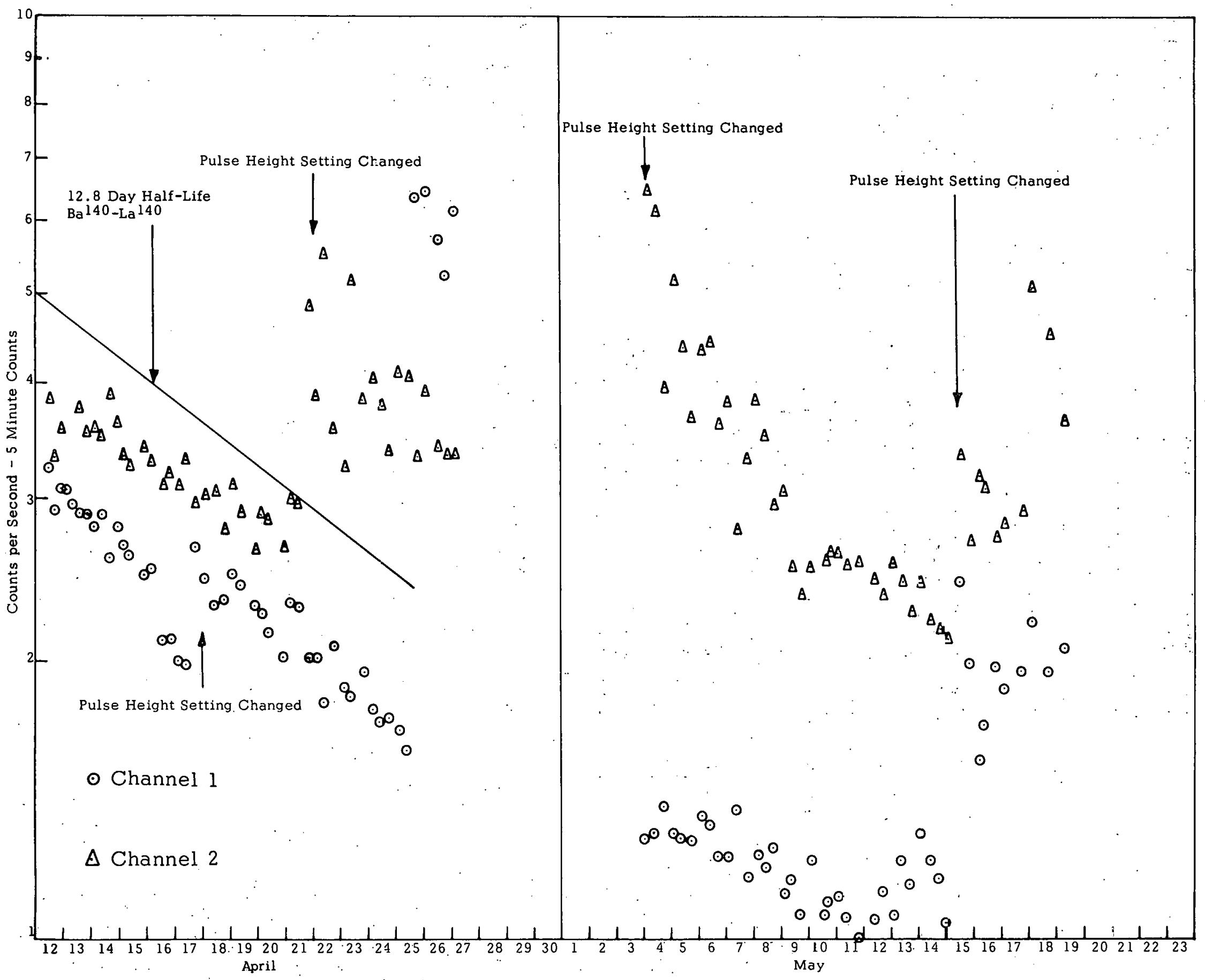


were obtained. These measurements are made routinely without interfering with the normal plant operation. However, during the training program, the required shutdown and/or operating conditions are not often available; so this test data is obtained whenever the required conditions. occur.

Table $4 \div 1$ is a tabulation of the bank positions determined during the period, October 1961 through May 1962. Figure 4.3 is a plot of the bank position as a function of energy release from the time of installation of Core II.

The data obtained during the October 1961 to May 1962 period appears to be good with the exception of that taken at 1.88 MWYR. The high bank positions determined at 1.88 MWYR were due to xenon which had not yet decayed a low level, because the shutdown duration was not $48 \mathrm{hr}$ or more, as required.

Figure 4.3 show. a discontinuity of the curves at 1.510 MWYR. This discontinuity is due to the removal of two high burnup elements S 8.0 and S81 during the October-November 1961 shutdown. This core loading change caused a net reactivity increase of about 2.1 dollars; as shown by the decrease in critical bank position. This is in good agreement with the predicted reactivity change of 2.18 dollars. (7), (8) The shape of the burnup curves is similar to that for $\mathrm{SM}-1$, as shown by the SM-1. Core. I curve (bottom curve). (6)

The loading changes during the April-May 1962 shutdown caused a negligible change in reactivity, and no change in bank position was observed.

TABLE $4-1$

FIVE ROD BANK POSITION VS CORE II ENERGY RELEASE

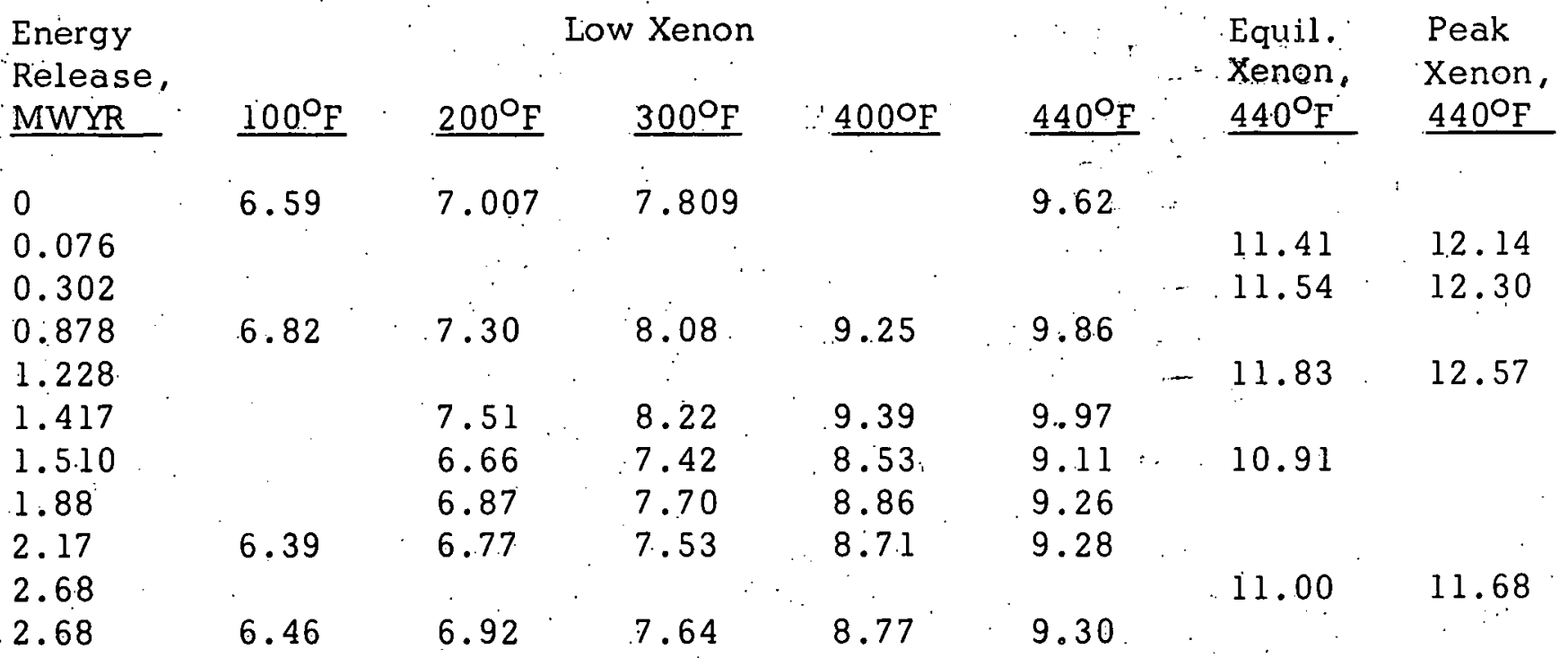




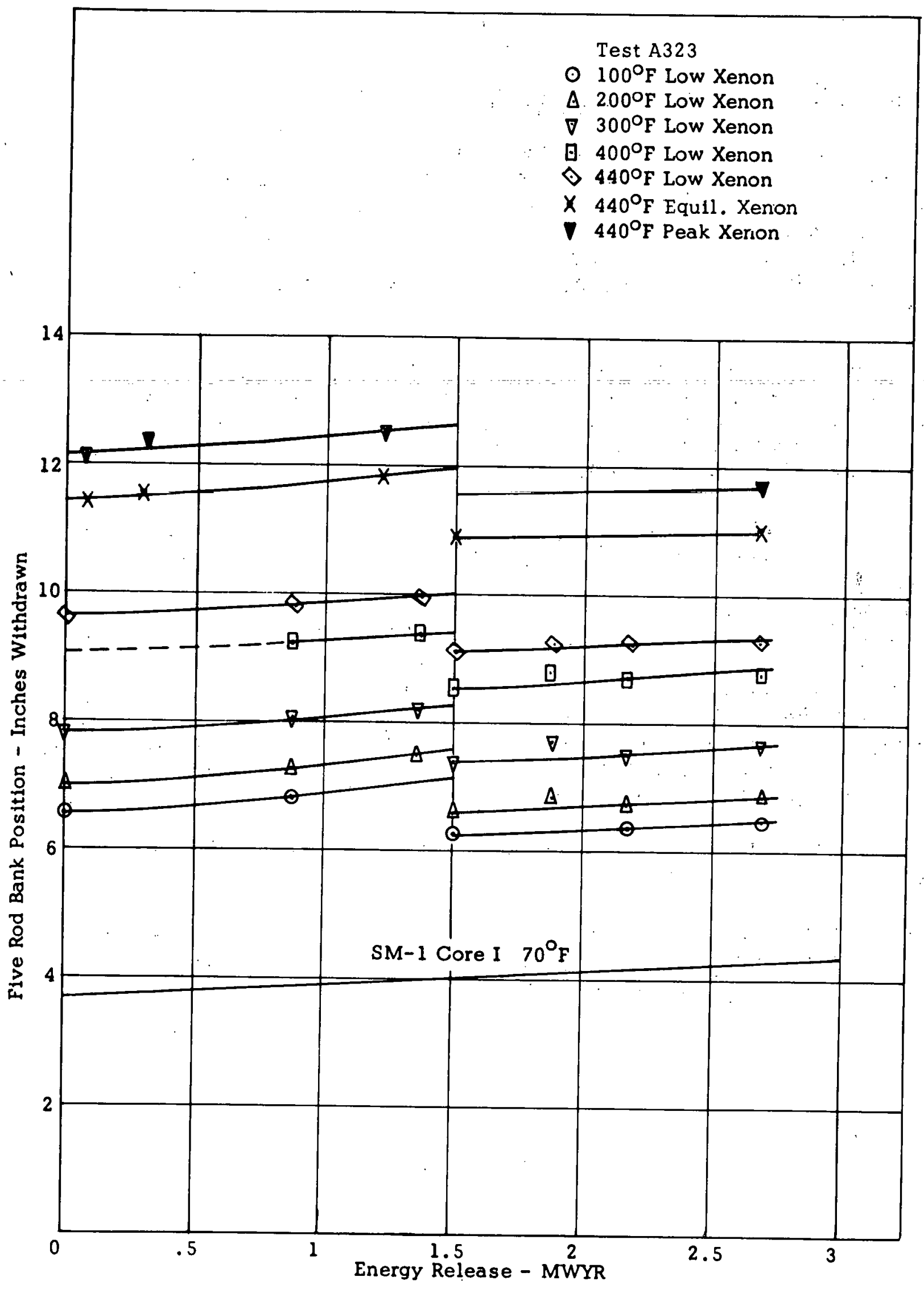

Figure 4.3 Five Rod Bank Position Vs Core II Energy Release 


\subsection{TEST A325-FIVE ROD BANK CALIBRATION}

The SM-1 Core II five rod bank was calibrated directly by the positive period method. Bank calibrations for Core I were determined indirectly from the integrated reactivity values of calibrated single control rods. (6) The difficulty of controlling the large reactivity of the bank was avoided in recent measurements by individually withdrawing each rod in the bank in turn approximately 0.1 in. and obtaining periods of the order of 25 to $100 \mathrm{sec}$ for the whole bank.

The calibration curve shown in Fig.4.4 includes those. data obtained up to the April-May 1962 core change, after which a new calibration curve was started. Figure 4.5 shows the new curve obtained after the April-May 1962 core change. Included in Fig.4.5, for comparison purposes, is the calibration curve generated after the October-November core change.

Within the limits of experimental error, there is no observable change.in the bank calibration curve since Core II startup. (5)

\subsection{TEST A326-CRITICAL ROD POSITIONS FOR STUCK ROD CONFIGURATIONS}

Critical rod configurations were monitored repeatedly to determine whether the requirement for stuck rod shutdown could be met by insertion of 80 percent of the available rod motion starting from the fully withdrawn configuration. Thus, 80 percent of 7 control rods means 5.6 rods can remain inserted and 1.4 rods fully withdrawn before the reactor becomes critical.

Table 4-2 tabulates the stuck rod measurements made at $1.8 \mathrm{MWYR}$ and 2.68 MWYR.

The 80 percent stuck rod requirement was met during each measurement. The minimum rod withdrawal achieving criticality required the full withdrawal of two rods plus the partial withdrawal of a third rod. 


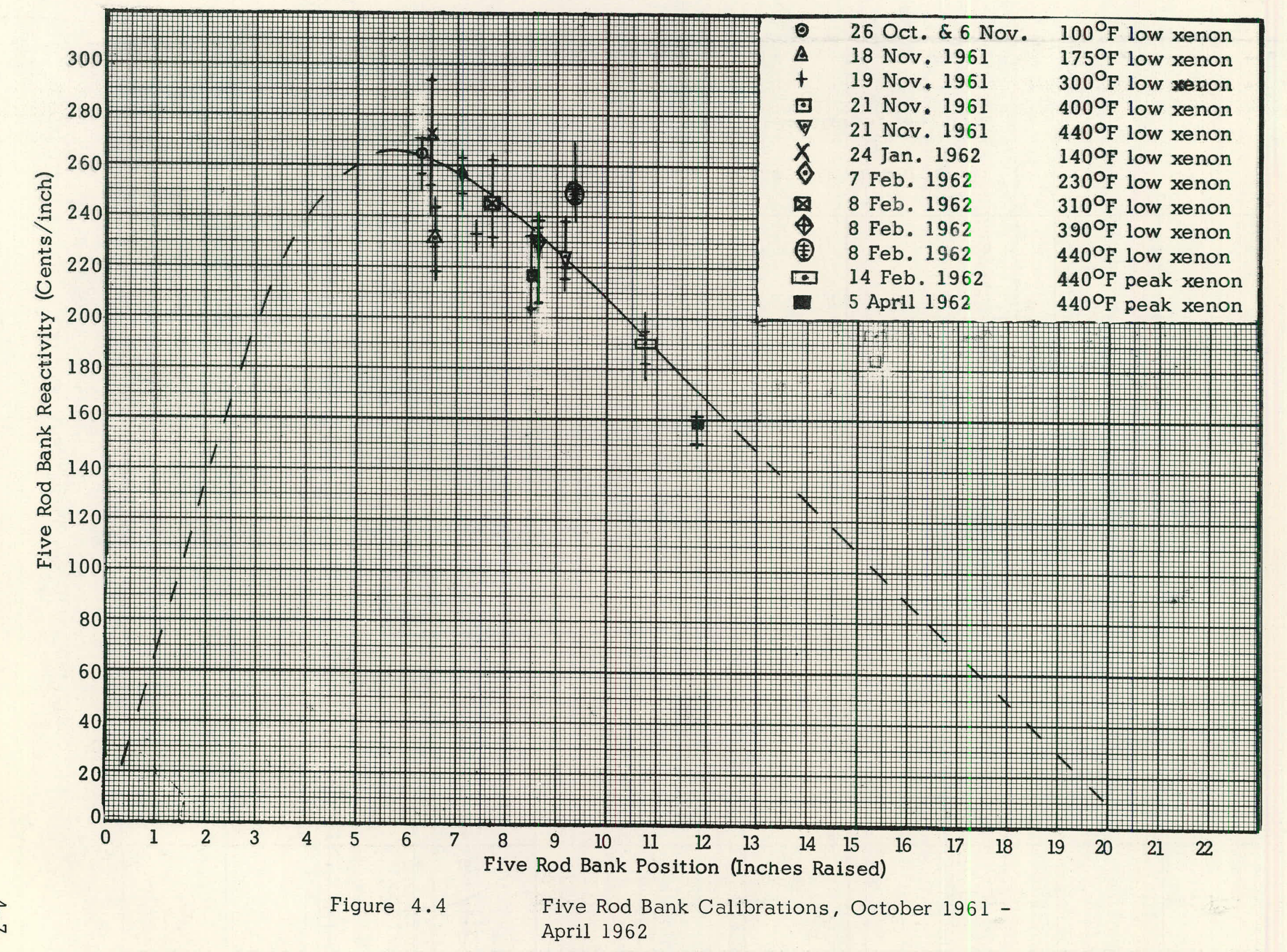




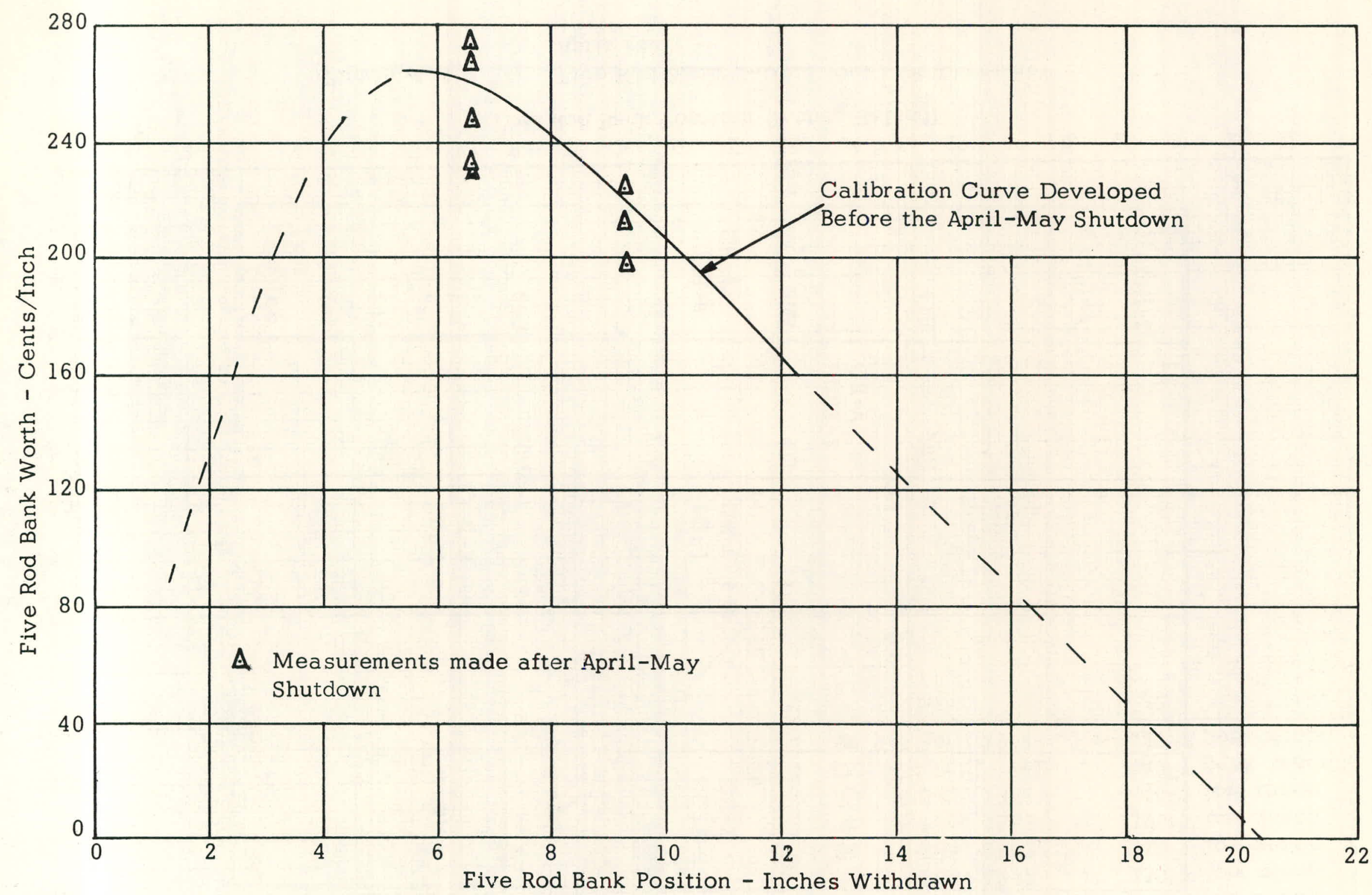

Figure 4.5. Five Rod Bank Calibrations, May 1962 
TABLE $4-2$

STUCK ROD MEASUREMENTS

1.8 MWYR, $200^{\circ} \mathrm{F}$ AND 75 PSIG, LOW XENON

\begin{tabular}{|c|c|c|c|c|}
\hline Case & $\begin{array}{l}\text { Rods Fully } \\
\text { Withdrawn } \\
\end{array}$ & $\begin{array}{c}\begin{array}{c}\text { Critical } \\
\text { Rod }\end{array} \\
\end{array}$ & $\begin{array}{c}\text { Critical Position, } \\
\text { In. } \\
\end{array}$ & $\begin{array}{l}\text { Worth } \\
\text { \&/inch }\end{array}$ \\
\hline 1 & A, 1 & C & 11.23 & 46.4k/in@11.43 in. \\
\hline 2 & $A, 1$ & 4 & 11.45 & $48.7 \xi /$ in @1. $1.64 \mathrm{in.}$ \\
\hline 3 & A, 4 & 1 & 9.58 & $34.4 \xi /$ in $@ 9.85$ in. \\
\hline
\end{tabular}

2.68 MWYR, $98^{\circ} \mathrm{F}$, ATMOSPHERIC PRESSURE, LOW XENON

\begin{tabular}{|c|c|c|c|}
\hline Case & $\begin{array}{l}\text { Rods Fully } \\
\text { Withdrawn } \\
\end{array}$ & $\begin{array}{c}\begin{array}{c}\text { Critical } \\
\text { Rod }\end{array} \\
\end{array}$ & $\begin{array}{c}\text { Critical Position, } \\
\text { In. }\end{array}$ \\
\hline 1 & A, 1 & 2 & 9,856 \\
\hline 2 & $A, 1$ & 3 & 17.151 \\
\hline 3 & $A, 1$ & 4 & 8,165 \\
\hline 4 & $A, 1$ & C & 7,610 \\
\hline 5 & A, 4 & 1 & 4,135 \\
\hline
\end{tabular}

\subsection{TESTS A308 AND A310-CONTROL ROD CALIBRATIONS}

Calibrated control rods are used for many reactivity measurements performed at the SM-1. The method of calibrating control rods is to bring the reactor critical with the rod to be calibrated while adjusting the rod bank to various positions. At the critical position, a worth measurement is made on the single rod by the positive period method. Due to the large worth of the individual control rods, there is a large interaction between rods; therefore, the rods worths are most accurate for the exact configuration used.

Control rods $\mathrm{A}$ and $\mathrm{C}$ were calibrated in May 1962 at temperatures of approximately $140^{\circ} \mathrm{F}$ and $435^{\circ} \mathrm{F}$. The calibration curves are shown in Fig. 4.6. and 4.7 . 
$\stackrel{\leftrightarrow}{1}$

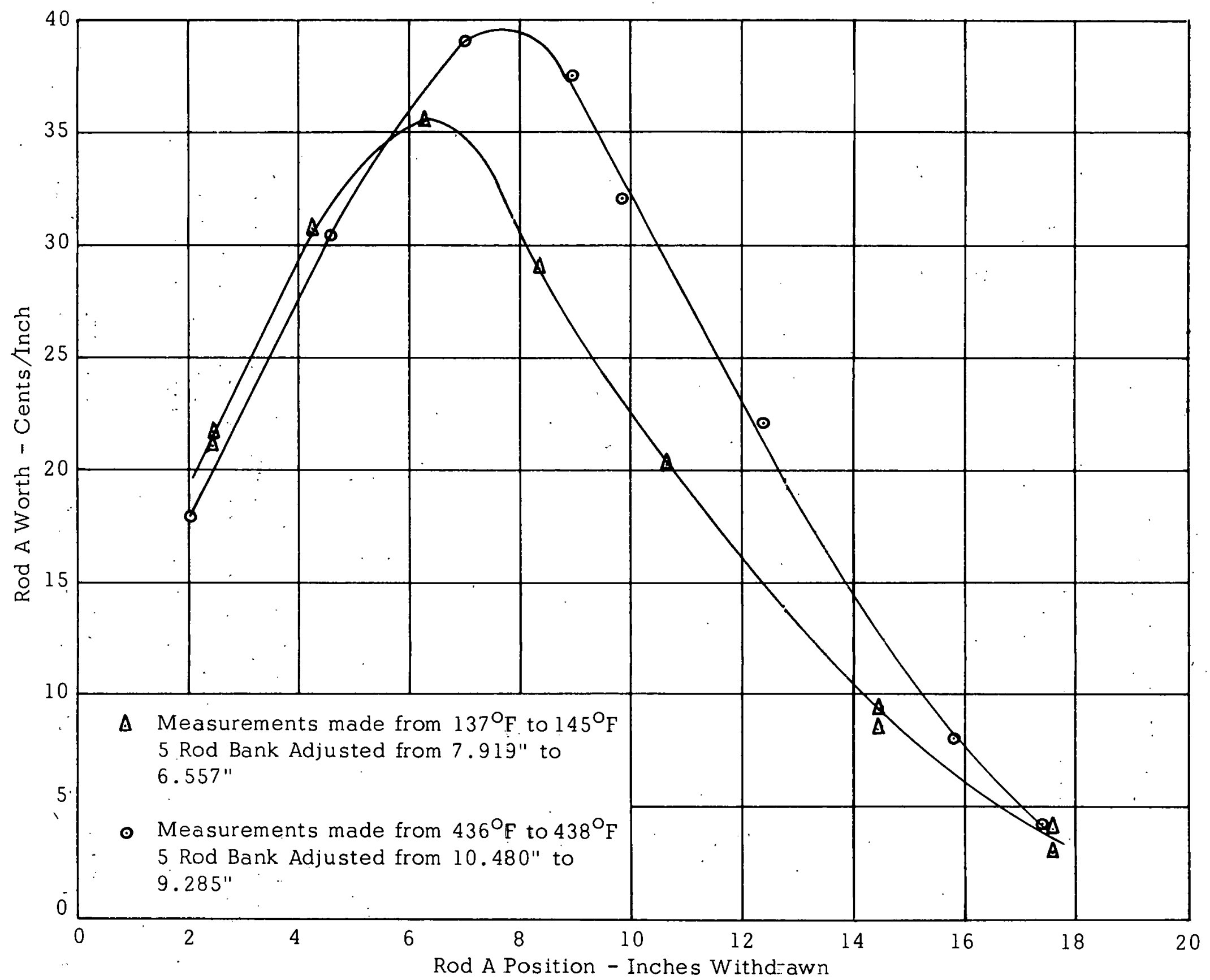

Figure 4.6. Control Rod A Calibrations 


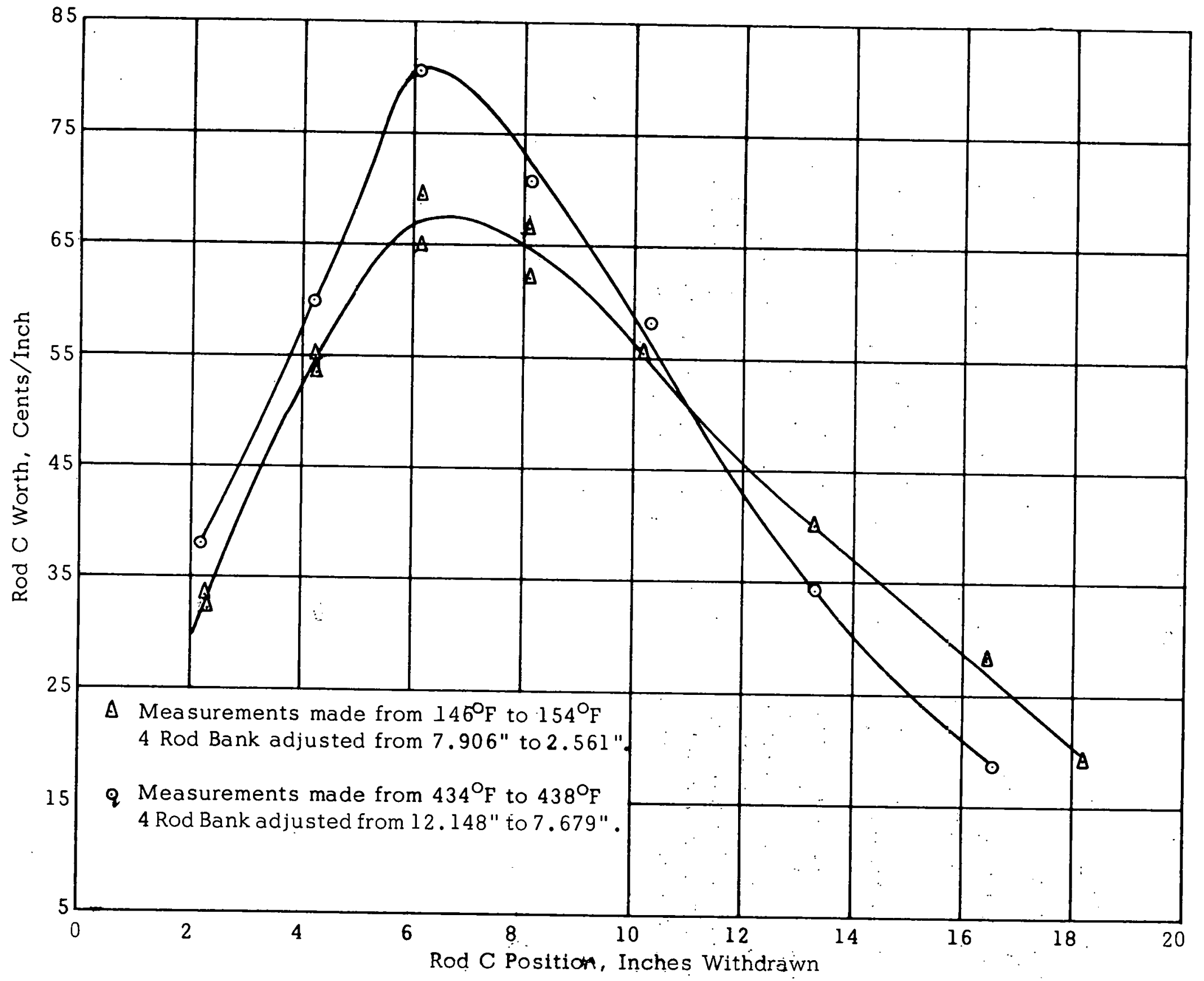

$\stackrel{\mapsto}{1}$

Figure 4.7. Control Rod C Calibrations 
The rod calibration curves show a displacement in the rod worth due to the different bank positions at high and low temperatures. The curves are similar to those for Core II startup (5) and Core I. (6)

\subsection{TEMPERATURE COEFFICIENT}

The temperature coefficient of reactivity was determined in May 1962 at $2.68 \mathrm{MWYR}$. The measurements were made over two temperature ranges: $173^{\circ} \mathrm{F}$ to $214^{\circ} \mathrm{F}$ and $401^{\circ} \mathrm{F}$ to $440^{\circ} \mathrm{F}$. The associated reactivity change with a change in core temperature was evaluated on calibrated control rod $\mathrm{A}$.

Table 4-3 is a tabulation of the data collected for the temperature coefficient . The temperature coefficient is plotted as a function of temperature in Fig. 4.8 .

Since the temperature coefficient was determined in only two regions, Fig. 4.8 represents only an approximation of the relative coefficient change with temperature. The relative reactivity worths of control rod $A$ were determined from Fig. 4.6. The temperature coefficient at $440^{\circ} \mathrm{F}$ was about 3.2 cents per $o_{F}$, which is somewhat lower than the value found for Core II startup (5) and for Core I (6). This difference in temperature coefficient is barely outside the limits of experimented accuracy, $(6)$ and has a negligible effect on. reactor properties. 


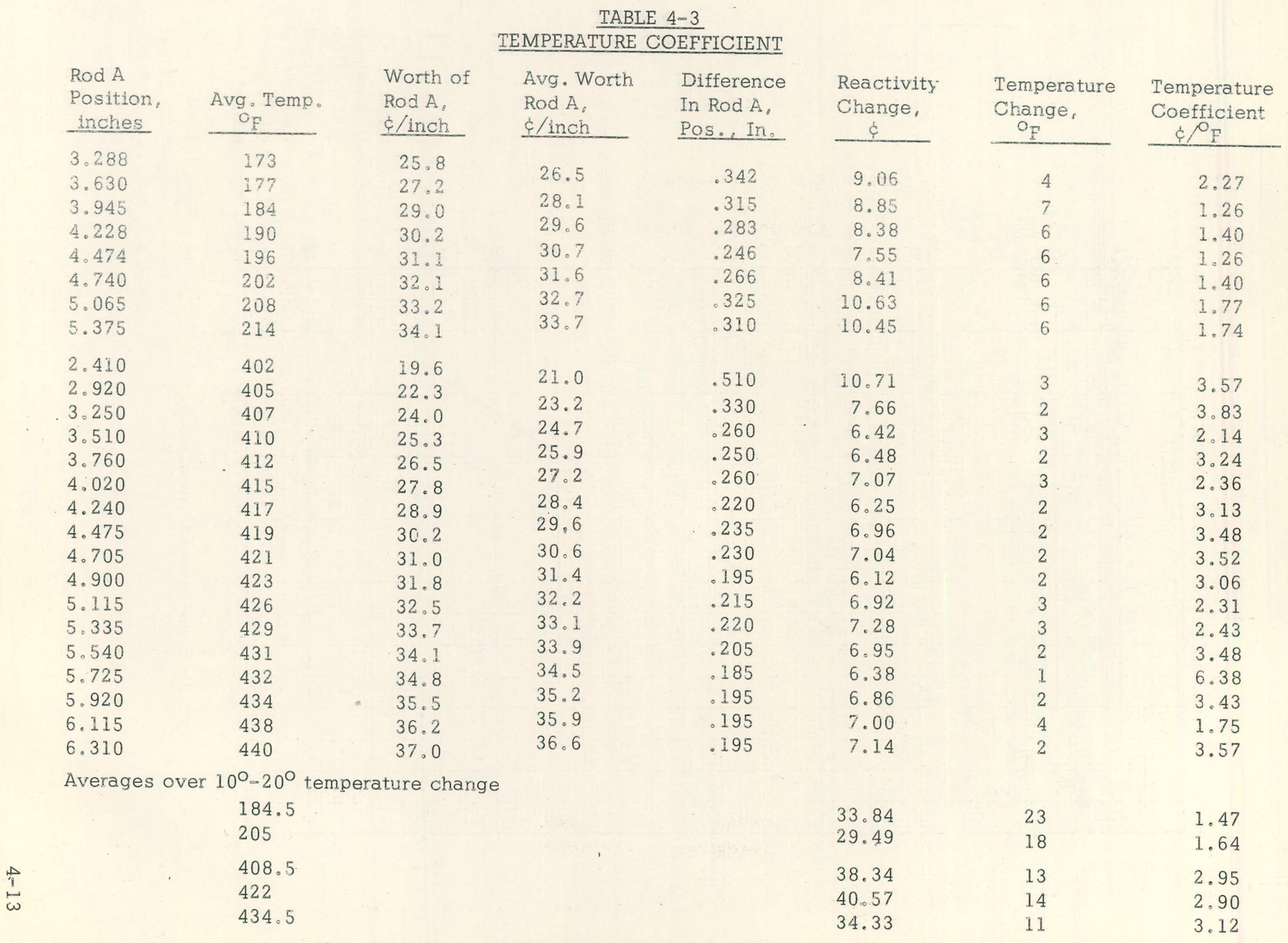




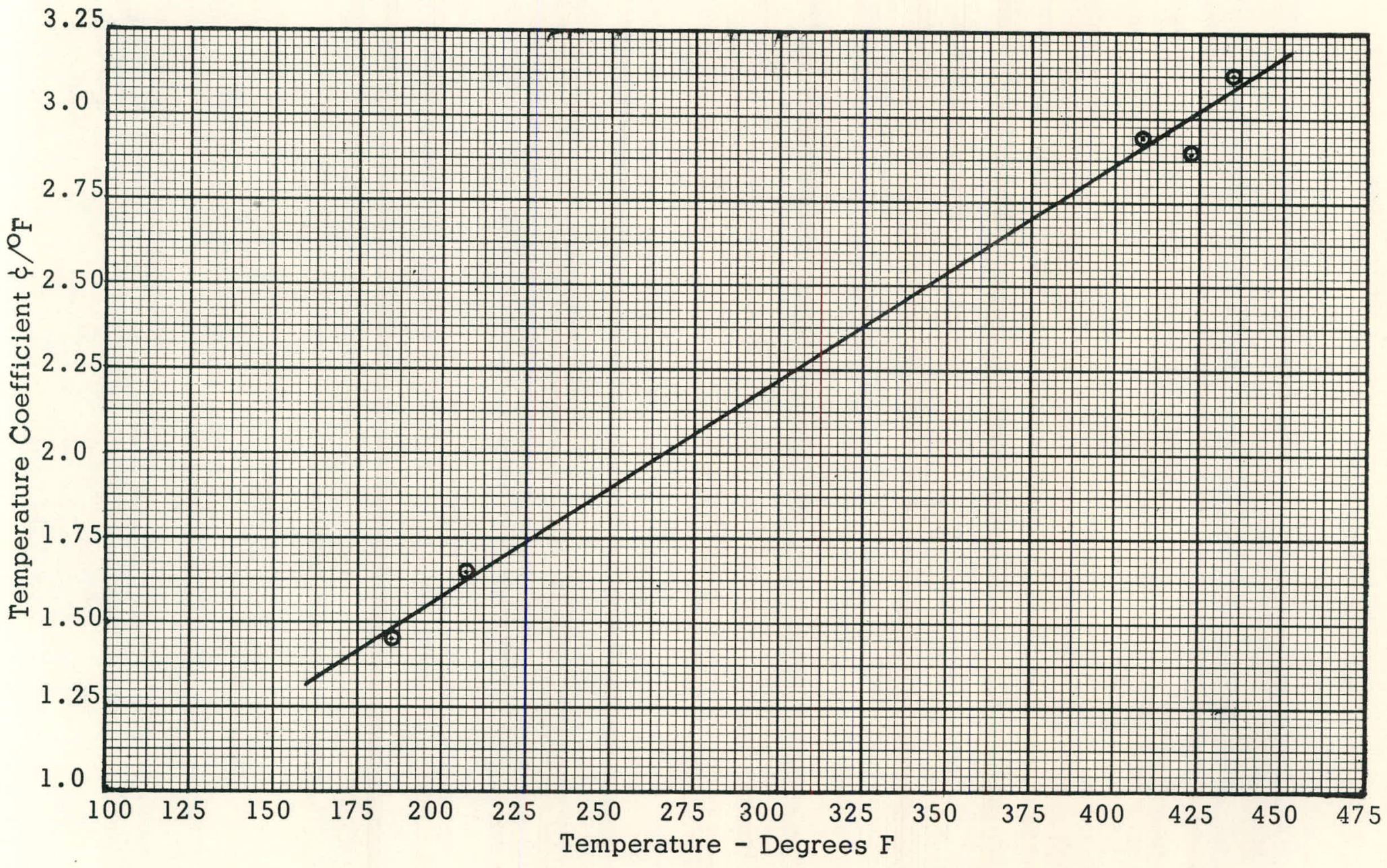

Figure 4.8. Temperature Coefficient 


\subsection{SHIELDING MEASUREMENTS}

\subsection{TEST A407 - ROD DRIVE PIT GAMMA RADIATION}

The objective of this test is to provide added basis for evaluation of the radiation levels in the rod drive pit area. The survey concentrates on mapping the areas of highest dose rate, in an effort to determine the source of the radiation. Previous radiation surveys were made prior to Core I removal and cleanup, after Core I removal, after flushing and cleanup of the bottom of the rearitor vessel, alld after completion of a two-day full power run on Core II. (9) The survey was repeated during the scheduled shutdowns in October 1961 and April 1962. In the latter case, a more detailed survey was made using film badges as well as portable survey meters. The radiation levels were determined at selected points in the rod drive pit using a Victoreen Model AG-50 BP ionization chamber with remote probe.

The dose rates obtained in October 1961 are listed in Table 5-1, and for April 1962 in Table 5-2. These indicate high readings adjacent to the seal flanges at the water box shield surface, behind the rod drive mounting plate, in the range of 12 to $18 \mathrm{R} / \mathrm{hr}$. The dose rates agree with previous surveys, within limits of experimental accuracy. The location of survey points is shown in Fig. 5.1.

These surveys confirm previous readings, (9) and there is no evidence of increasing radiation levels. It is recommended that this survey be repeated at semi-annual shutdown periods to as sure that radiation levels are not increasing.

TABLE 5-1

GAMMA RADIATION SURVEY OF SM-1 ROD DRIVE PIT, OCTOBER 1961

Location

4 In, $x 4$ In. wood shield on the left side up

center

down

Along the bottom slot between water box and concrete

Test points 19 and 20 (upper left and lower right hand corners of mounting plate)

Adjacent to the seal flanges at the water box shield surface, behind the rod drive mounting plate

Background in the accessible working area near the drive cables
Dose Rate, $\mathrm{R} / \mathrm{hr}$

3.0

2.5

1.5

2.0 and 2.5 .

0.8 and 2.5

12 to 15

0.2 to 0.3 
TABLE 5-2

GAMMA RADIATION SURVEY OF SM-1 ROD DRIVE PIT, APRIL 1962

Survey Instrument: Victoreen Radector

Film: Removed April 19, 1962 following a $24 \mathrm{hr}$ exposure

Reactor Shutdown: April 5, 1962

Survey Meter

Film

Survey Point Description of Location

Reading $\mathrm{R} / \mathrm{hr}$ Reading $\mathrm{R} / \mathrm{hr}$

i Water box surface at Rod No. 4 penetration

15

3.5

2

Water box surface between Rod No. 4 and Rod A penetration

$--\quad 8.74$

Water box surface at Rod No. 1 penetration

15

24.60

$4 \quad$ Water box surface between Rod A and Rod \#1 penetration

Water box surface at Rod. C penetration

12

$18: 30$

6

Front face, mounting plate between Rod

No. 4 and Rod A penetration

1.81

7. Front face, mounting plate, between

Rod $A$ and Rod 4 penetration

1.6

1.56

9 Front face, mounting plate, between Rod A and Rod 1 penetration

2.1

7.30

10 Front face, mounting plate, between Rod C and Rod 1 penetration

Front face, mounting plate, near rod C

13 Vertical crack between water box and frame, top

14 Left vertical wood frame, top

2.1

1.71

Vertical crack between water box and frame, center

4.0 


\begin{tabular}{|c|c|c|c|}
\hline Survey Point & Description of Location & $\begin{array}{l}\text { Survey Meter } \\
\text { Reading } \mathrm{R} / \mathrm{hr} \quad \mathrm{H}\end{array}$ & $\begin{array}{l}\text { Film } \\
\text { Reading } \mathrm{R} / \mathrm{hr}\end{array}$ \\
\hline 17 & $\begin{array}{l}\text { Vertical crack between water box and } \\
\text { frame, bottom }\end{array}$ & 1.2 & \\
\hline 18 & Left vertical wood frame, bottom & 1.3 & . \\
\hline 19 & $\begin{array}{l}\text { Bottom slot between water hnx and } \\
\text { concrete left }\end{array}$ & 1.5 & 0.895 \\
\hline 20 & $\begin{array}{l}\text { Bottom slot between water box and } \\
\text { concrete center }\end{array}$ & 5.5 & 2.44 \\
\hline 21 & $\begin{array}{l}\text { Bottom slot between water box and } \\
\text { concrete right }\end{array}$ & 1.7 & 1.19 \\
\hline 23 & Horizontal wood frame, center & -- & 1.67 \\
\hline 25 & $\begin{array}{l}\text { Ceiling (bottom of shield tank) near } \\
\text { wood frame, left }\end{array}$ & -- & 0.625 \\
\hline 26 & $\begin{array}{l}\text { Ceiling (bottom of shield tank) near } \\
\text { wood frame, center }\end{array}$ & -- & 0.833 \\
\hline 28 & $\begin{array}{l}\text { Ceiling (bottom of shield tank) one } \\
\text { foot out, left }\end{array}$ & $-\infty$ & 0.541 \\
\hline 29 & $\begin{array}{l}\text { Ceiling (bottom of shield tank) one foot } \\
\text { out, center }\end{array}$ & -- & 0.562 \\
\hline 134 & $\begin{array}{l}\text { Water box surface at Rod No. } 2 \\
\text { penetration }\end{array}$ & -- & 12.5 \\
\hline 139 & $\begin{array}{l}\text { Water box surface at Rod No. } 2 \\
\text { penetration }\end{array}$ & -- & $1 \hat{1} .545$ \\
\hline Background & Accessible areas & 0.1 to 0.3 & 0.2 \\
\hline
\end{tabular}




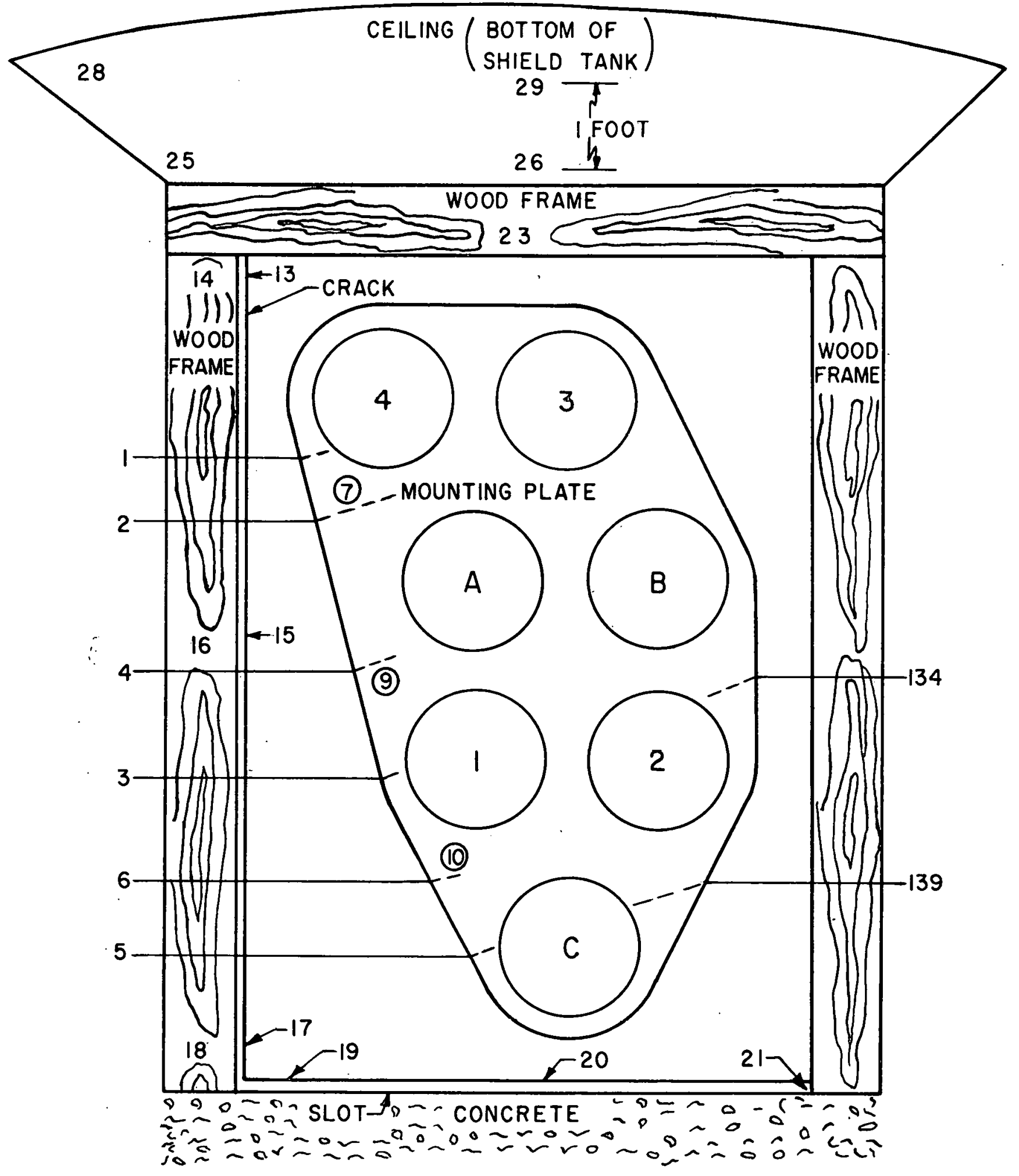

Figure 5.1 Radiation Survey Point Location - Rod Drive Pit 


\subsection{TEST A408 - GAMMA DOSE RATE FROM SPENT FUEL ELEMENT}

The overall test objective is to provide gamma dose rate measurements during transfer of spent fuel elements in order to check design calculations for the shield tank, spent fuel pit, and shipping casks, and to optimize future shield designs. Measurements were taken during this six-month period to determine Co-60 activity in the stellite flux suppressor combs attached to control rod fuel elements. This data will be used in the handling of elements for the removal of the flux suppressors from the fuel element assemblies.

The gamma dose rate was measured 6 in. above the surface of the water vertisally above a spent fuel element in the spent fuel pit: Measurements in inches of water above the fuel element centerline were made at dose rates of $200 \mathrm{mr} / \mathrm{hr}, \mathrm{l} \mathrm{R} / \mathrm{hr}$, and $2 \mathrm{R} / \mathrm{hr}$. Background was measured six inches above the surface of the water. Data for four control rod elements and one stationary element are tabulated in Table 5-3. Fig. 5.2 shows the data plotted as dose rate against water depth.

Figure 5.2 curves are in agreement with Test A408 results previously reported in APAE-35, Supplement 2 (9). Dose rates from control rod fuel elements CR-10, CR-11, CR-12 and CR-16 agree closely with those from CR-13, removed in May 1959. All of these elements have stellite flux suppressors above the fuel, about $11.5 \mathrm{in}$. above the fuel centerline. The dose rates are a factor of ten or more higher than from stationary fuel element S-62, due to the Co-60 activation in the stellite flux suppressors and the 11.5 in. less water shielding. The slopes of all five attenuation curves are similar, indicating that the dose rate at this water depth results from gamma radiations with energies greater than $1 \mathrm{Mev}$, similar to Co-60. 
TABLE 5-3

GAMMA RADIATION DOSE RATES FROM SM-1 CORE I SPENT FUEL ELEMENTS

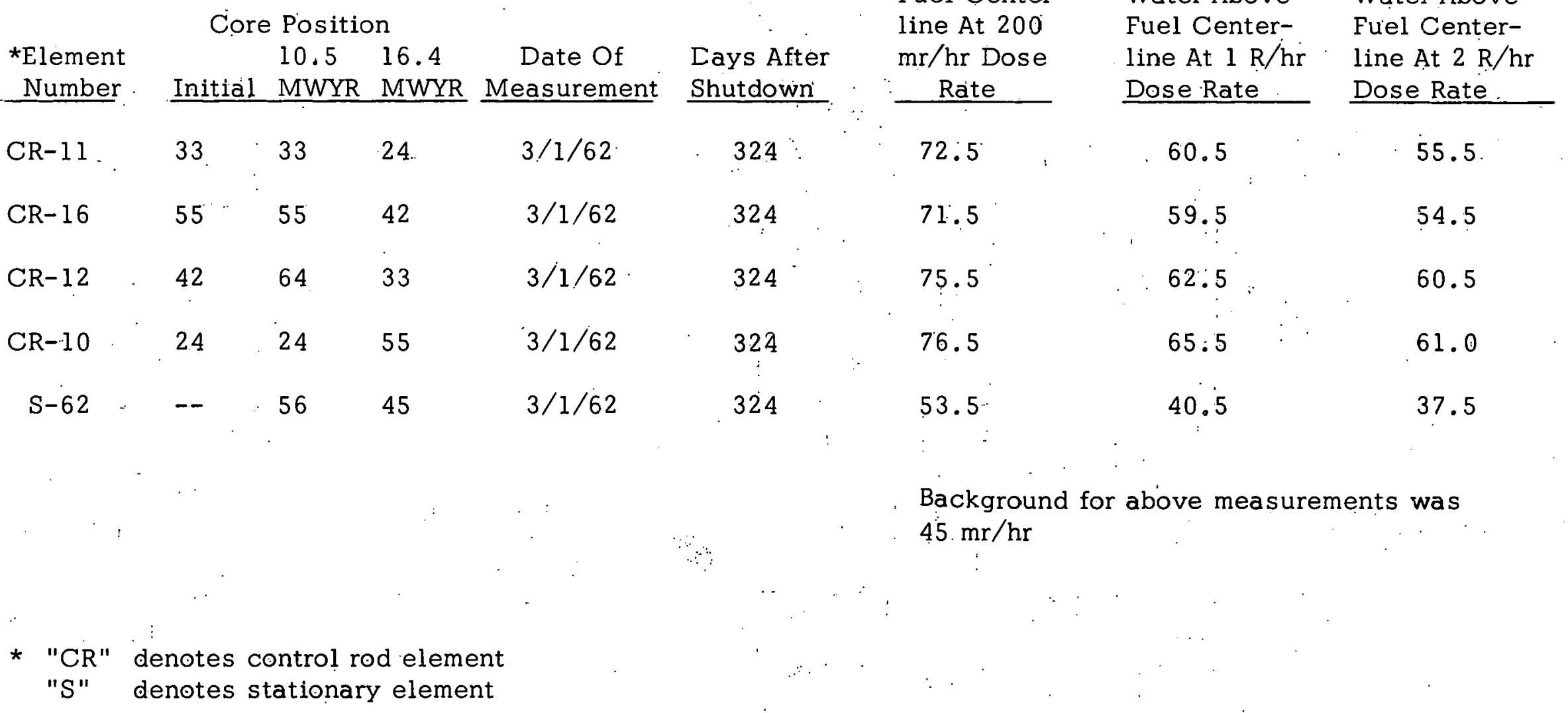

Inches Of

Water Above Inches Of Inches Of

Fuel Center- Water Above Water Above

line At 200 Fuel Center- Fuel Center-

$\mathrm{mr} / \mathrm{hr}$ Dose

h

Fine At $2 \mathrm{R} / \mathrm{hr}$

Number Initial MWYR MWYR Measurement Shutdown

"S" denotes stationary element 


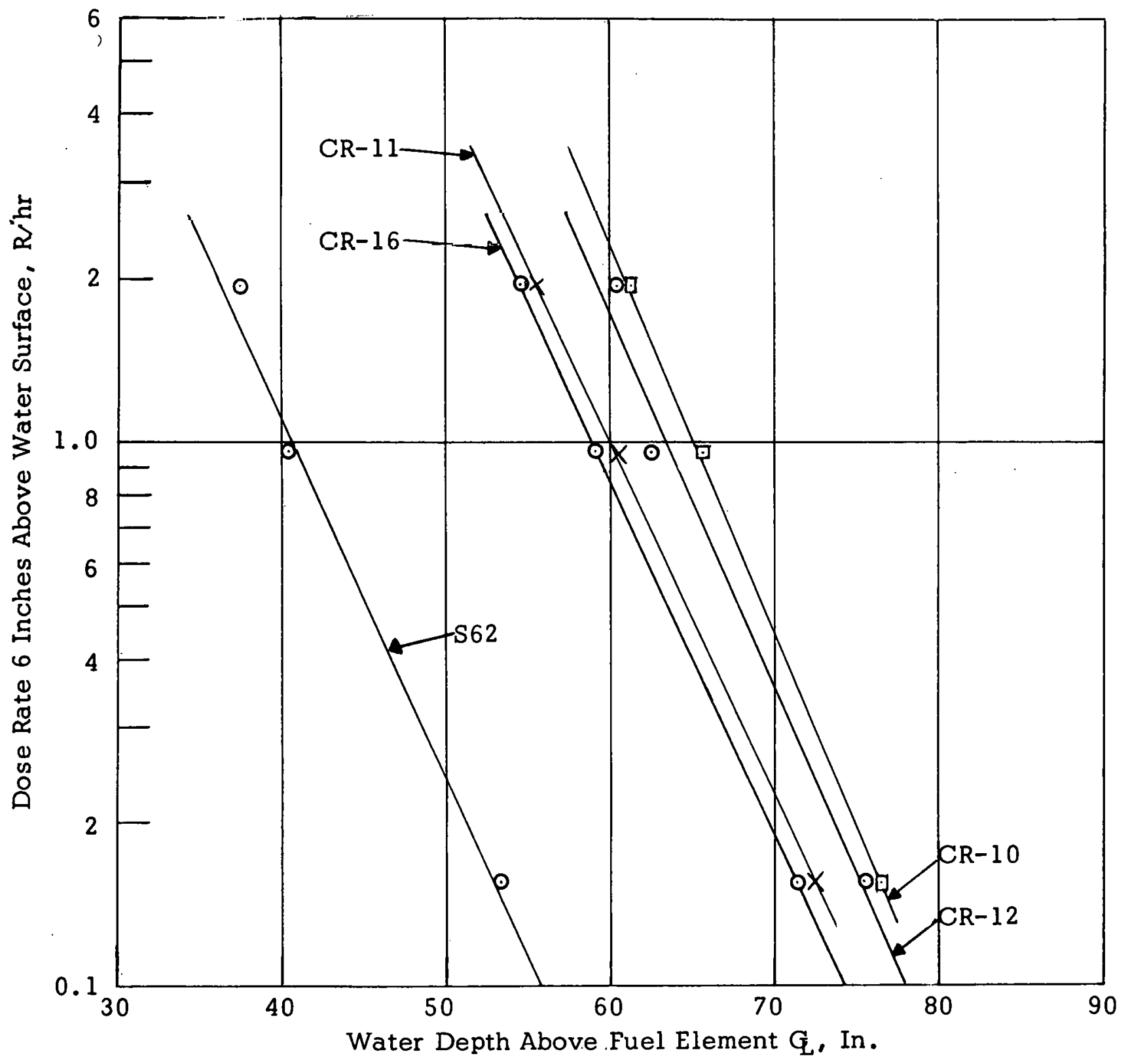

Figure $\quad 5.2$ Gamma Radiation Dose Rate from Spent Fuel Elements 


\subsection{NUCLEAR INSTRUMENTATION}

\subsection{TEST A503 - LIFTING MECHANISM FOR STARTUP CHANNEL BF 3 COUNTER}

The purpose of this mecharism is to improve the operational characteristics of the startup channel and to increase the useful life of the $\mathrm{BF}_{3}$ detector.

The $\mathrm{BF}_{3}$ lift mechanism was installed at the $\mathrm{SM}-1$ in November 1961, and preliminary tests were run to verify both the mechanical and electrical operation. The mechanical operation was satisfactory, and the new vapor container penetration met leakage specification. Some signal attenuation occurred when the $\mathrm{BF}_{3}$ chamber was connected to the lift mechanism cable. This attenuation, in conjunction with other channel trouble either in the chamber or preamplifier was sufficient to prevent the regular use of the lift mechanism. One test was run, however, of count rate versus chamber height. Preliminary evaluation of the electrical problem indicated that more extensive analysis and testing was required of the cable chamber and startup channels than could be scheduled at the SM-1 plant.

Two leak tests were made of the Pyle connector at the SM-1 plant. One test consisted of applying 5 psig helium to the connector from inside the vapor container. The connector was sealed with glyptol, and readings at five points on the connector ranged from $8.54 \times 10^{-9}$ to $5.15 \times 10^{-8}$ atmos $\mathrm{cc} / \mathrm{sec}$. The other test consisted of bench testing the connector without glyptol sealant at 5 psig and 30 psig helium. Readings at five points on the connector were as high as $1.705 \times 10^{-5}$ atmos $\mathrm{cc} / \mathrm{sec}$. Data from the one test of count rate versus chamber height in Well "B" are given in Table.6-1. Figure 6.1 shows the data plotted along with a curve of gold foil activation at corresponding heights in Well "A". The activation data was reported in APAE- 35 , Supplement 2, issued March 16, $1962^{(9)}$.

From the results of this one test and the fact that the $\mathrm{BF}_{3}$ count rate curve is in good agreement with the activation curve, it can be concluded that the $\mathrm{BF}_{3}$ lift mechanism will serve its purpose well whenever the signal attenuationstartup channel troubles are resolved. The Pyle connector with glyptol seal successfully met the leakage limitations of $1 \times 10^{-6}$ atmos $\mathrm{cc} / \mathrm{sec}$. for vapor container penetrations. 
TABLE 6-1

STARTUP CHANNEL.LIFT MECHANISM

COUNT RATE VS BF 3 CHAMBER HEIGHT

Test Run : $\quad$ November 17,1961

Constants: High Voltage. $\quad$ : 1750

Pulse Height Setting : $\quad 140$

Gain : : $\quad 64 \times 1$

Band Width $\quad \cdot \quad: \quad 0.5 \mathrm{mc}$

Bank Position : : 0

Temperature : $\quad 113$

Pressure . : : Atmospheric

$\mathrm{BF}_{3}$ Chamber Position,

Inches From Bottom of Well "B"

0

6

12

18

24

30

36

42

48

54

60

66

72
Count Rate, Counts $/ 5 \mathrm{~min}$.

413

399

394

254

168

176

65

57

43

27

26

24 


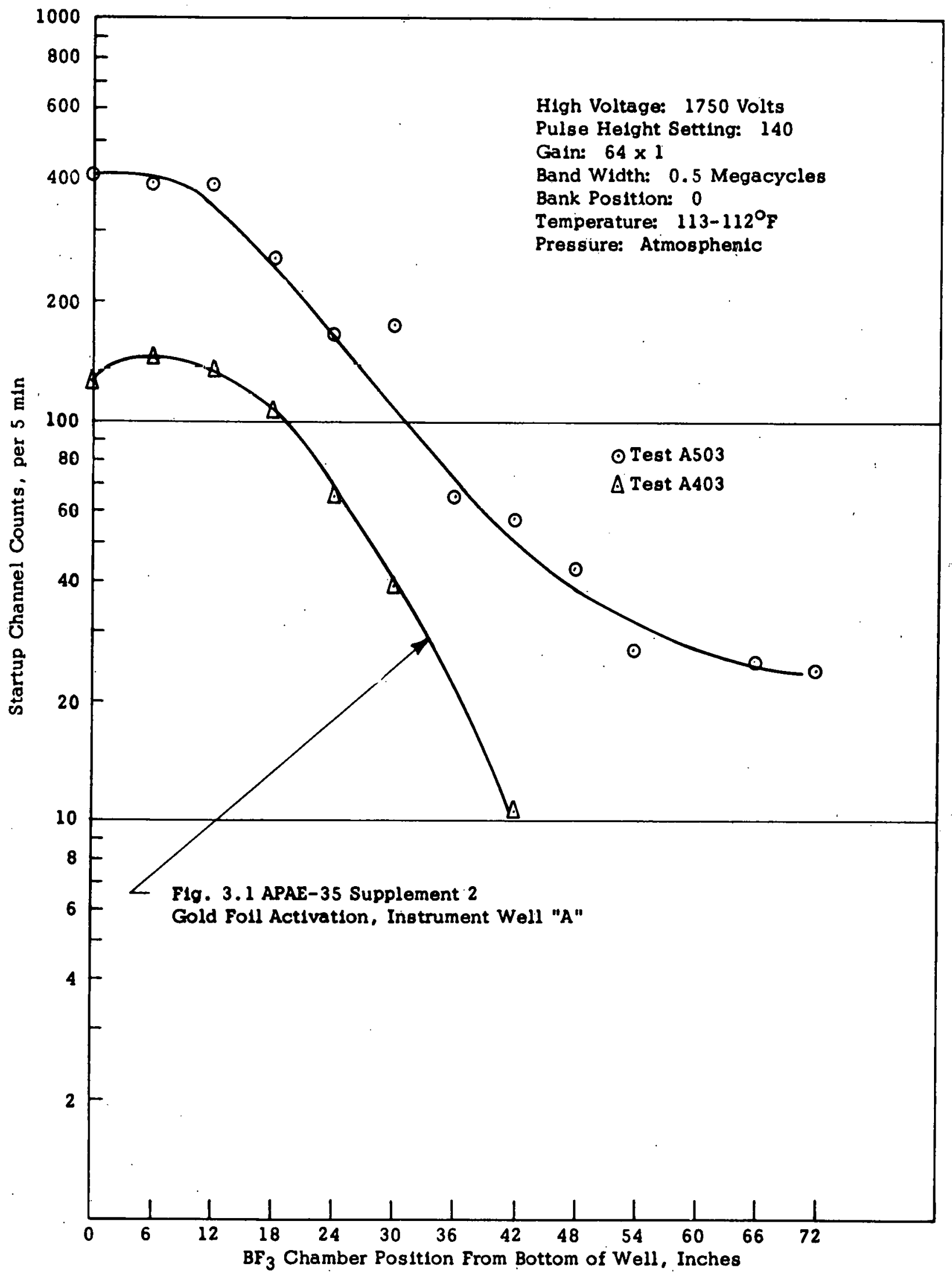

Figure 6.1 Startup Channel Count Rate Vs BF3 Chamber Height 


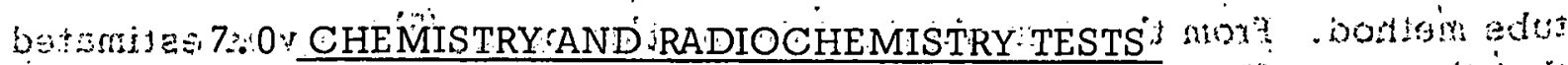

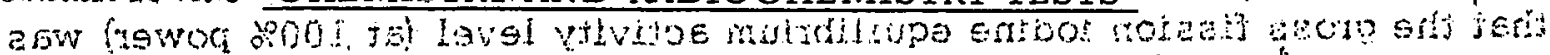

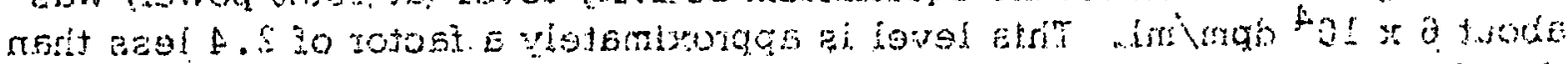

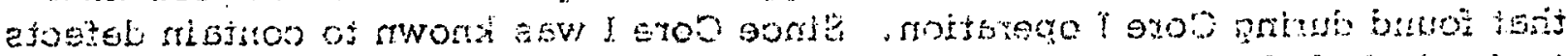

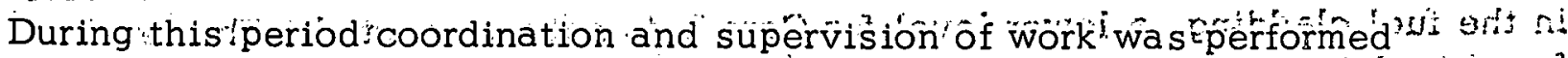

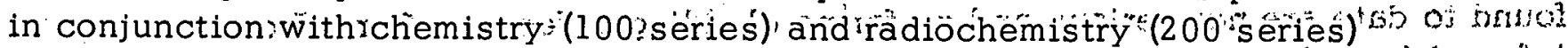
tests being carried out at the SM- 1 1ro $A$ summary of the work performed and résults tordate of the tests is given below! Details of the results of the tests us

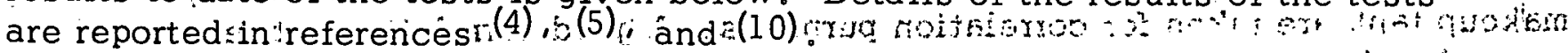

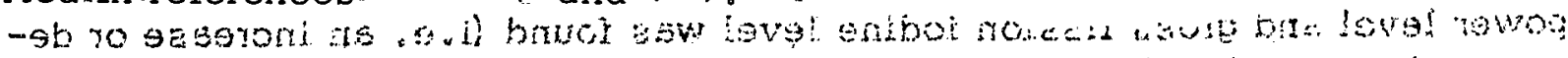

7.1 TEST:A109-EVALUATION OF INDUSTRIALINSTRUMENTS MODEL OA-I $505 \%$

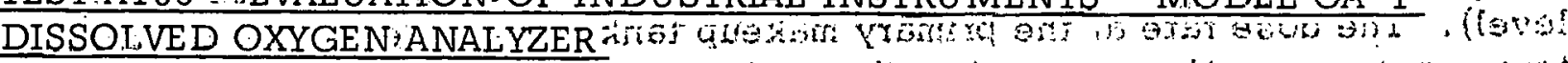

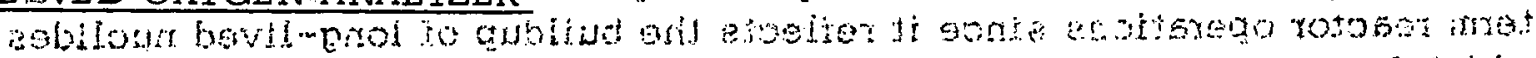

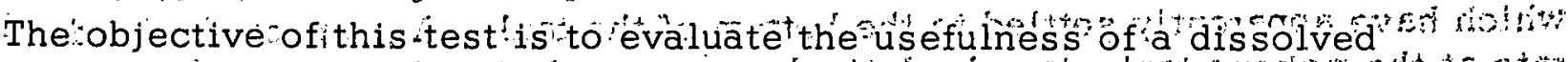

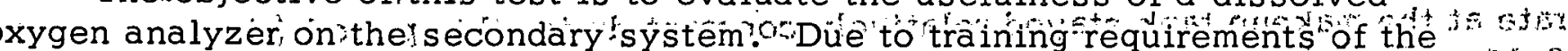
$\mathrm{SM}-1$; this test was not run this period. Arrangements were made to purchas $\mathrm{e}^{2} \mathrm{n},-, \mathrm{z}$ the analyzer from the vendor, since it had been accuired on a loan basis .

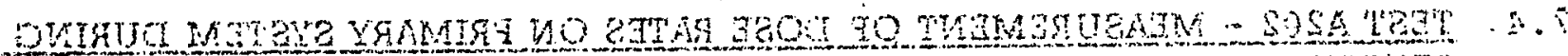

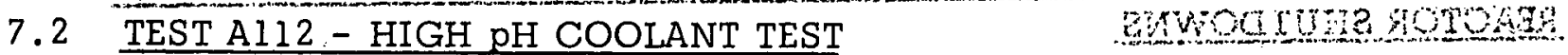

The objective of this test is' to determine the effects of high pHa colant

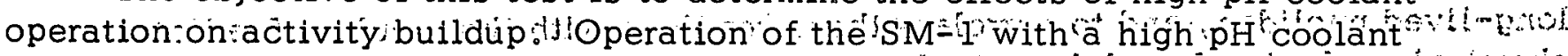

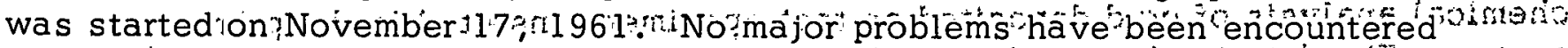
during the operation. the initial startup:and'on minor:operating problem s?

$\rightarrow$ (Tests A202\%A214, A215 and A2 16) taken on primary system and demineralizer \% stit

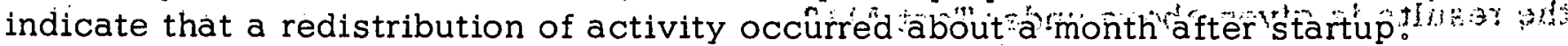

.. Primary system and demineralizer dose rates increased faster than usual. However, after several months of high $\mathrm{pH}$ operation the radiation levels in the

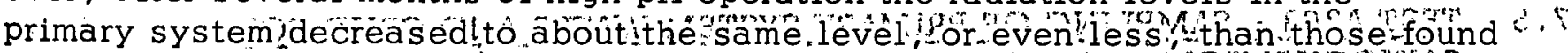

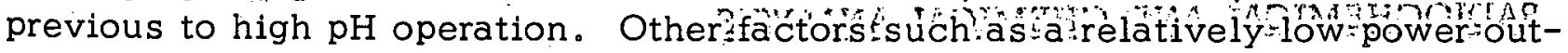
put of the reactor during this period, and the use of low cobalt stainless steel in

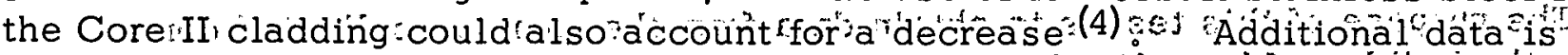

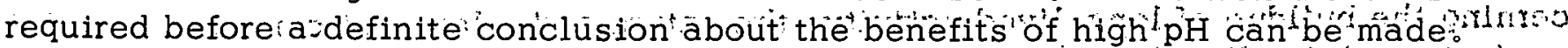

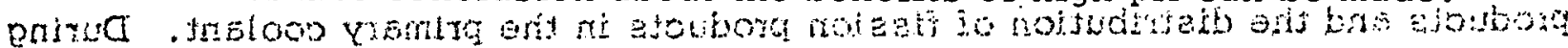

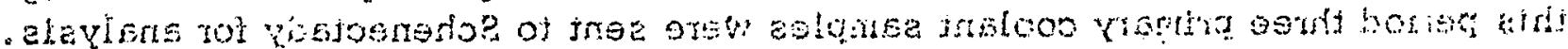

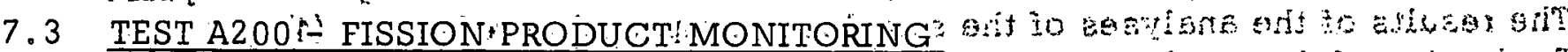

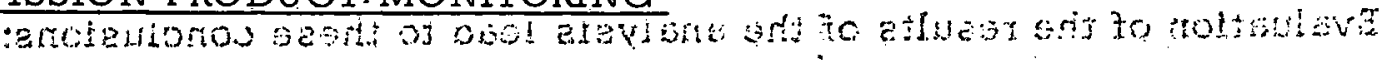

The objective of this test is to alert the operating crew of a faulty or ruptured fueltelement by the detection 'of gros sfission product io dine in the a

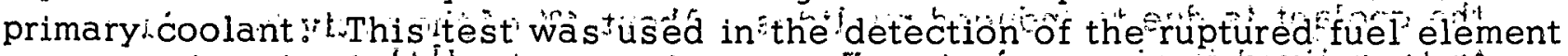
that occurred?ón Octóber 5 , 1960 lot The data collected by this transient is used as the sba'se line for the detection of a ruptured fuel element? "Gross fission product:iodine levels were mea sured frequently" since Core II startup in 'June 1961 . Two methods rof determining the gross iodine levels were employedo d.

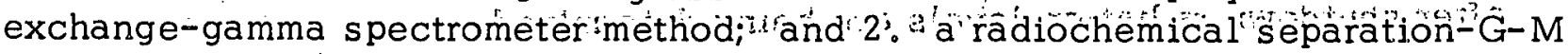


tube method. From the data obtained during this period (5), it was estimated that the gross fission iodine equilibrium activity level (at 100\% power) was about $6 \times 10^{4} \mathrm{dpm} / \mathrm{ml}$. This level is approximately a factor of 2.4 less than that found during Core I operation. Since Core I was known to contain defects in the fuel cladding, a lower level for Core II is not unexpected. The levels found to date are not serious and so far no cladding defects in Core II can be inferred from the data. In addition to gross fission iodine levels, data on daily reactor operations and radiation levels at the fence around the primary makeup tank are taken for correlation purposes. A good correlation between power level and gross fission iodine level was found (i.e. an increase or decrease in power level is affected by an increase or decrease in gross iodine level). The dose rate at the primary makeup tank is more dependent on long term reactor operations since it reflects the buildup of long-lived nuclides which have apparently settled to the bottom of the tank. As expected, the dose rate at the makeup tank stayed relatively constant during this period (about $8-10 \mathrm{mr} / \mathrm{hr}$ ).

\subsection{TEST A202 - MEASUREMENT OF DOSE RATES ON PRIMARY SYSTEM DURING REACTOR SHUTDOWNS}

The objective of this test is to determine the change in dose rate due to long-lived nuclides, and to correlate these readings with the results of radiochemical analysis of crud deposited on test specimens inserted in the primary system. The data is also used to evaluate the effects of high $\mathrm{pH}$ operation. During this period four separate dose rate surveys were made. These included one prior to high $\mathrm{pH}$ operation and three during high $\mathrm{pH}$ operation. A summary of the results is given above under Test Al12.

\subsection{TEST A203 - SAMPLING OF PRIMARY SYSTEM WATER AND CRUD FOR RADIOCHEMICAL AND CHEMICAL ANALYSIS}

The purpose of this test is to obtain data from the samples collected concerning the buildup of long-lived activity, the nature and release of corrosion products and the distribution of fission products in the primary coolant. During this period three primary coolant samples were sent to Schenectady for analysis. The results of the analyses of the samples are reported in reference (4) and (10). Evaluation of the results of the analysis lead to these conclusions:

1. About $93 \%$ of long-lived gamma activity in the non-filterable portion of the coolant is due to induced nuclides. About $4 \%$ of the activity is due to long-lived fission products. From previous work, (11) the distribution of significant nuclides (Co60, Co ${ }^{58}$ ) is roughly the same in the filterable portion as in the non-filterable portion of the coolant. Thus, it appears that activity levels of the nuclides which cause the major portion of after shutdown radiation levels are being determined. 
2. Investigation of the $\mathrm{Co}^{58} / \mathrm{Co}^{60}$ ratio in the total coolant during the past year (1961) showed that other mechanisms, besides the release of activity from core cladding, are contributing significantly to longlived activity levels. The other mechanisms would include: (1) activation of out-of-flux corrosion products deposited on and subsequently released from in-flux components; and (2) a redistribution of activated corrosion products deposited on primary system surfaces possibly due to high oxygen levels, high pH operation, or a physico-chemical phenomenon related to the insertion of a "clean" core at Core II startup. If the above mechanisms are responsible for a significant amount of activity the use of low cobalt in core cladding material will not be as beneficial as originally thought.

Samples of water from the spent fuel element shipping casks were also. sent to Schenectady during this period. Results of the analyses showed that the elements were leaking fission products at a rate greater than. that acceptable at ICPP. As a result, it was recommended that separate storage containers for the fuel elements be purchased and sent to the ICPP for their use upon arrival of the elements at the site.

\subsection{TEST A204 - SAMPLING OF METAL COUPONS FOR RADIOCHEMICAL AND}

The purpose of this test is to obtain data from metal coupons inserted in the SM-1 purification system to determine the corrosion and deposit thickness rate of various metals and to aid in understanding mechanisms of activity transport along with data from Test A202 and A203. Two groups of coupons removed in October, 1961 and April, 1962 were sent to Schenectady for analyses. Results of the analyses of the October 1961 samples are included in reference 4 . The percent distribution of induced nuclides removed from the coupon deposits showed that $80 \%$ of the activity is due to the Co60 - Co58 nuclides. Data obtained during Core I operation (1 1), showed that about $75 \%$ of the total long-lived induced activity was due to the above cobalt nuclides. Due to an additional reactor operation time, an increase in the cobalt nuclide contribution is not unexpected.

\subsection{TEST A213 - SHORT-LIVED ACTIVITY AND DECAY RATES OF PRIMARY SYSTEM
WATER AND CRUD}

The purpose of this test is to determine the relative proportions of the shortlived nuclides in the primary coolant and crud; and to study the changing distribution of these with reactor age. This test was performed twice during this period. Evaluation of the data appears in reference (4). In summary, it was found that greater than $90 \%$ of the total activity levels in the coolant was due to shortlived (less than $2.5 \mathrm{hr}$ half-life) nuclides in a sample taken on August 14, 1961. In a sample taken on March 20, 1962 about 75\% of the total coolant activity 
was due to short-lived nuclides. A review of reactor operations prior to the two sampling periods showed that the lower percentage found in the March 20, 1962 was not unexpected since the reactor had operated at a lower power level when compared to operations prior to the August 14, 1961 samples.

\subsection{TESTS A2 14, A215, A216 - DOSE RATES ON THE DEMINERALIZER DURING OPERATION AND AFTER SHUTDOWN}

The purposes of these tests are to determine the overall efficiency of the demineralizers to remove activity from the primary loop and to correlate data obtained under Tests A203 and A204. During this period Tests A214 and A215 were each performed twice, and Test A216 was performed on a daily basis. Evaluation of the data is summarized above in Test Al12. In addition, data taken from Test A21.6, which involves daily measuring of the dose rate on top of the demineralizer, showed a good correlation between reactor operations as could be experted.

\subsection{TEST A220 - DETERMINATION OF $\mathrm{Mn}^{56}, \mathrm{Cs}^{138}$, and Ba ${ }^{139}$ CONCENTRATIONS IN SM-1 PRIMARY COOLANT}

The purpose of this test is to provide additional data on the transport and behavior of activity in a PWR. Since the above nuclides are all short-lived $(2.5 \mathrm{hr}$ half-life or less) the reactor has to be at power for only $24 \mathrm{hr}$ in order to obtain equilibrium data. This test was attempted once this period with the aid of Schenectady personnel. However, due to the length of time required to take. the filterables into solution, only limited data on the non-filterables were. obtained. The data obtained. was not sufficient for evaluation. 


\subsection{REFEREǸNESS}

1. Brown, W. S. and Dixon, M。H. "Fiscal Year 1962 Program Plan for Engineering Support and Development of Army Pressurized Water Reactor Power Plants,"AP Note-378,Alco Products Inc。, September 6。1961。

2. Moote, F。G。 "Test Program for the SM-1 Reactor, Period October 1961 to March 1962" "October 6. 1961.

3. Moote, F. G。, "Test Program for the SM-1 Reactor, March 1962 to S'eptember 1962,"March 12; 1962,

4. Dixon, M. H. "Six Months Summary Report, October 1, 1961 to March 31 。 1962, Army PWR Support and Development Program," APAE-113。 May 25. 1962 .

5. Moote, F。G. and Schrader, E. W . "startup and Initial Testing of SM-1 Core II with Special Components " APAE Memo-305, February 28, 1962.

6. Weiss, S. H. "Summary Report of Physics Measurements on SM-1 Core $\mathrm{I}_{\diamond}$ " APAE-96, February 6, 1962 .

7. Coombe, J。R. "Hazards Report for the SM-1 Core II with Special Components" APAE-84, April 30, 1961: '(Also APAE-84, Addendum II, September 1, 1961.

8. Lee, D。H. Robinson, R. Ä. Segalman, I. "Experiments and Analysis for SM-1 Core II with Special Components," APAE-85, April 26, 1961 .

9. Moote, F. G。, and Obrist, C. H. "Shielding Measurements at the SM-1. Reactor (June 1961)。"APAE-35, Supplement 2。 March 16, 1962 。

10. Bergmann, C.A. and Bergen,C.R., "Summary of Work Performed on Subtasks 5.1 and 5.2 from April 1, 1962 to June 20, 1962,"AP Note-435, Alco Products Inc。, July 1962 .

11. Bergmann, C。A., "Long-Lived Induced Activity Buildup During SM-1 Core I' Lifetime," APAE-77, November 30, 1960. 